\title{
Lipase B from Candida antarctica Immobilized on Epoxy- functionalized Hollow Silica Microspheres: Efficient Biocatalysts for Enantiomer Selective Acylation of Alcohols and Amines
}

\author{
Márk Oláh1', Szandra Suba1, Zoltán Boros², Péter Kovács³, Mathilde Gosselin", \\ Charles Gaudreault , Gábor Hornyánszky1,2* \\ 1 Department of Organic Chemistry and Technology, Faculty of Chemical Technology and Biotechnology, \\ Budapest University of Technology and Economics, H-1111 Budapest, Múegyetem rkp. 3, Hungary \\ 2 SynBiocat LLC., H-1172 Budapest, Szilasliget u. 3, Hungary \\ ${ }^{3}$ Institute of Organic Chemistry, Research Centre for Natural Sciences, Hungarian Academy of Sciences, \\ H-1117 Budapest, Magyar tudósok kt. 2, Hungary \\ ${ }^{4}$ Materium Innovations INC., Boulevard Industriel 790, J2G 9J5 Granby, Canada \\ ${ }^{*}$ Corresponding author, e-mail: hornyanszky@mail.bme.hu
}

Received: 10 May 2018, Accepted: 05 June 2018, Published online: 01 October 2018

\begin{abstract}
Hollow silica microspheres with promising physical properties (MAT540 ${ }^{\mathrm{TM}}$ ) as support for enzyme immobilization and biocatalyst were investigated in this study. The amine-functionalized MAT540'М was activated by six bisepoxides inclosing different spacers and used as epoxy-functionalized carrier for immobilization of lipase B from Candida antarctica (CaLB). The novel, covalently fixed CaLB biocatalysts were compared in kinetic resolution (KR) of racemic 1-phenyethanol rac-1 and five racemic amines rac-3a-e using shaken flasks and continuous-flow packed-bed microreactors. Mechanic stability, re-usability and the effect of temperature $\left(0-90{ }^{\circ} \mathrm{C}\right)$ on productivity and enantiomer selectivity of the covalently immobilized CaLB were investigated. The best performing CaLB biocatalyst showed good mechanic stability after $24 \mathrm{~h}$ operation time in continuous-flow mode at $60^{\circ} \mathrm{C}$ and provided in KRs of racemic 1-phenyethanol rac-1 with vinyl acetate and of five racemic amines with isopropyl 2-ethoxyacetate as acylating agent the non-reacted (S)-alcohol [(S)-1] or (S)-amines $[(S)$-3a-e] and the forming $(R)$-ester $[(R)$-2] or $(R)$-amide $[(R)-4 a-e]$ in good yields with high enantiomeric excess (ee $>99 \%$, for all).
\end{abstract}

Keywords

alcohol, amine, biocatalysis, continuous-flow mode, kinetic resolution

\section{Introduction}

Chirality is a key property of organic fine chemicals in the field of agrochemical [1], pharmaceutical [2, 3] and food industries $[4,5]$. Consequently, there is an ever increasing demand for optically pure final products especially by active pharmaceutical ingredients [6-8] where particularly hydroxyl $[9,10]$ and amine [11] functions or their derivatives [12] are bound to the center of asymmetry. Asymmetric techniques, such as aldol reaction [13], epoxide opening [14], ketone reduction [15] or kinetic resolution of racemic mixtures [16] are well known methods to produce pure enantiomers of alcohols. On the other hand, synthesis of enantiopure amines can rely on asymmetric synthesis catalyzed by chiral metal-ligand complexes [17], differential crystallization of their diastereomeric salts with chiral ligands [18, 19] and diverse resolution methods [20]. It is important to note that most of asymmetric chemical catalysts have their biopair in form of enzymes and applied as biocatalyst such as oxidoreductases [21, 22], transferases [23], hydrolases [24] or lyases [25]. In this context, lipases (triacylglycerol ester hydrolases, EC 3.1.1.3) [26] have gained popularity in laboratory and industrial scale as well since they can perform kinetic resolution [27] both of alcohols and amines in aqueous [28] or in organic medium [29] and do not require any cofactors during the catalytic process.

Selectivity, specificity, catalytic activity and stability are key factors that substantially affect the application of 
enzymes as industrial biocatalysts [30, 31]. With the aim to improve these properties and focusing on the recovery of enzymes, different immobilization techniques were evolved [32-38]. It is crucial to keep the immobilized enzyme in active and stable for many reaction cycles [39-41]. For immobilization of lipases, fixing on solid supports $[42,43]$ is the most known method enabling heterogeneous catalysis in batch reactions [44] or in continuously operated packed-bed bioreactors [45-47].

Covalent attachment of enzymes onto solid supports is based on a stable bound formation, therefore it requires the activation of enzyme or support (or both) [48, 49]. This kind of enzyme immobilization requires several steps including modification and activation of support surface and enzyme coupling [50]. Covalent bond formation between aldehyde functions on the support - usually obtained by activation of aminated surfaces with glutaraldehyde - and amine functions of the enzyme is one of the most commonly used coupling methods [33, 42], involving Schiff's base formation between surface exposed nucleophilic amino groups (mostly terminal amino functions of Lys) and the aldehyde moieties. This hydrolytically unstable Schiff's base type bond is often reduced by sodium borohydride treatment to prevent further enzyme release and to transform the residual aldehydes on the carrier to less active hydroxyl groups [51]. Besides aldehydes, epoxy-activated carriers are also applied to immobilize enzymes under mild conditions (e.g. $\mathrm{pH}=7.0$ ). Besides being epoxy-carriers storable for long terms, they can provide biocatalysts of improved stability after the ring opening reactions due to the non-hydrolysable nature of the formed covalent bonds with the protein (secondary amine, ether, thioether structures may be formed) [52-61]. In addition, mixed-functionalization of surfaces by two or more functions involving reactive and inert moieties allows fine tuning the properties of support (such as polarity and functional group density) [62-64]. Two methods are widely applied for surface functionalization of the carriers, the direct co-condensation synthesis applying epoxy-containing monomers and the post-synthesis surface grafting methods [65]. Surface grafting is a process for modification of surface by covalently linking species with reactive groups. The most conspicuous advantage is the good preservation of carrier before or even after the surface functionalization [66]. In case of carrier-bound enzymes, the quality of solid support is another key factor to create a productive immobilized biocatalyst. In this context, high protein binding-capacity, high surface-to-volume ratio, insolubility in application medium, high mechanical, thermal, chemical stability contributing to efficient recoverability are crucial factors in support selection. Carriers can be divided into two groups according to their porosity, the porous and nonporous carriers and each have their own limits and benefits [67]. In porous carriers, enzyme could be fixed mostly within the pores of the system resulting in high enzyme loading capacity due to the high specific area of carrier. However, porous systems suffer from considerable mass transfer limitations depending on the porosity, particle diameter and shape (pore size and volume) which all can influence diffusion rate [68] and the kind of reactors where the biocatalyst may be utilized $[69,70]$.

In this study, hollow silica microspheres (M540: MATSPHERES $^{\circledR}$ series 540; Materium Innovations) were chosen as promising carrier for immobilization of lipase B from Candida antarctica (CaLB). M540 microspheres were developed for bio applications such as support to enhance microorganism's growth, immobilization of enzymes, and additives for concentration or purification of biomolecules. Accordingly, M540 microspheres have promising properties for enzyme immobilization: high surface-to-volume ratio $\left(>100 \mathrm{~m}^{2} / \mathrm{g}\right)$, proper particle size for batch and packed-bed continuous-flow bioreactor applications $(10-30 \mu \mathrm{m})$, dispersibility in water and in organic solvents as well and easy functionalisability owing to the presence of amine groups on the surface.

Herein, we present a detailed study on application of M540 silica carriers for covalent immobilization of $\mathrm{Ca}$ LB and biocatalytic application (batch and continuous-flow modes) of the resulted biocatalysts.

\section{Experimental Section}

\subsection{Materials}

Isopropyl 2-ethoxyacetate was synthesized as described previously [47], all other solvents and chemicals were purchased from the following companies Sigma Aldrich (Saint Louis, MO, USA), Alfa Aesar Europe (Karlsruhe, Germany), Merck (Darmstadt, Germany) and used as received. Lyophilized Lipase B from Candida antarctica was purchased from c-LEcta (Leipzig, Germany).

M540 was the product of Materium Innovations (Granby, Canada). M540-AE, M540-BE, M540-CE, M540-DE, M540-EE, M540-FE supports were the products of SynBiocat LLC. (Budapest, Hungary). These bisepoxide-activated derivatives of the M540 hollow silica microspheres were prepared according to a previously published method [71]. CV T2-150 dry acrylic beads (150$300 \mu \mathrm{m}$ particle size) were the product of ChiralVision BV 
Table $1 \mathrm{GC}$ data of investigated compounds (oven programs and $t_{R}$ )

\begin{tabular}{|c|c|c|c|}
\hline $\mathrm{KR}$ & Oven program & Comp. & $t_{R}(\min )$ \\
\hline \multirow{4}{*}{$r a c-1$} & \multirow{4}{*}{$120^{\circ} \mathrm{C}$ isothermal, $8 \mathrm{~min}$} & $(S)-\mathbf{1}^{\mathrm{a}}$ & 3.4 \\
\hline & & $(R)-\mathbf{1}^{\mathrm{a}}$ & 3.7 \\
\hline & & $(R)-2^{\mathrm{a}}$ & 4.6 \\
\hline & & $(S)-\mathbf{2}^{\mathrm{a}}$ & 4.8 \\
\hline \multirow{5}{*}{$r a c-3 a$} & \multirow{3}{*}{$\begin{array}{l}100-180^{\circ} \mathrm{C}^{\circ}{ }^{\circ} \mathrm{C} \mathrm{min}^{-1}, 5 \mathrm{~min} \\
\text { at } 180{ }^{\circ} \mathrm{C}\end{array}$} & $(S)-\mathbf{3} \mathbf{a}^{\mathrm{b}}$ & 2.8 \\
\hline & & $(R)-\mathbf{3} \mathbf{a}^{\mathrm{b}}$ & 3.0 \\
\hline & & $(R, S)-\mathbf{4 a}^{\mathrm{b}}$ & 10.7 \\
\hline & \multirow{2}{*}{$\begin{array}{l}100-180{ }^{\circ} \mathrm{C} 4{ }^{\circ} \mathrm{C} \mathrm{min}^{-1}, 5 \mathrm{~min} \\
\text { at } 180{ }^{\circ} \mathrm{C}\end{array}$} & $(S)-4 \mathbf{a}^{\mathrm{a}}$ & 17.3 \\
\hline & & $(R)-\mathbf{4} \mathbf{a}^{\mathrm{a}}$ & 17.6 \\
\hline \multirow{4}{*}{$r a c-\mathbf{3 b}$} & \multirow{2}{*}{$140-170^{\circ} \mathrm{C} 1^{\circ} \mathrm{C} \mathrm{min}^{-1}$} & $(R, S)-\mathbf{3 b}^{\mathrm{b}}$ & 2.5 \\
\hline & & $(R, S)-\mathbf{4} \mathbf{b}^{\mathrm{b}}$ & 25.4 \\
\hline & \multirow{2}{*}{$140-170{ }^{\circ} \mathrm{C} 1{ }^{\circ} \mathrm{C} \min ^{-1}$} & $(S)-4 \mathbf{b}^{\mathrm{a}}$ & 26.2 \\
\hline & & $(R)-4 \mathbf{b}^{\mathrm{a}}$ & 26.7 \\
\hline \multirow{5}{*}{$r a c-3 \mathbf{c}$} & \multirow{3}{*}{$\begin{array}{l}5 \mathrm{~min} \text { at } 120^{\circ} \mathrm{C}, 120-180{ }^{\circ} \mathrm{C} \\
6^{\circ} \mathrm{C} \min ^{-1}, 10 \mathrm{~min} \text { at } 180{ }^{\circ} \mathrm{C}\end{array}$} & $(R)-\mathbf{3} \mathbf{c}^{\mathrm{b}}$ & 7.3 \\
\hline & & $(S)-\mathbf{3} \mathbf{c}^{\mathrm{b}}$ & 7.4 \\
\hline & & $(R, S)-\mathbf{4} \mathbf{c}^{\mathrm{b}}$ & 27.4 \\
\hline & 40 min at $140^{\circ} \mathrm{C}, 140-155^{\circ} \mathrm{C}$ & $(S)-4 \mathrm{c}^{\mathrm{a}}$ & 69.8 \\
\hline & $\begin{array}{l}0.5^{\circ} \mathrm{C} \mathrm{min}^{-1}, 155-180{ }^{\circ} \mathrm{C} \\
5^{\circ} \mathrm{C} \mathrm{min}^{-1}, 5 \mathrm{~min} \text { at } 180^{\circ} \mathrm{C}\end{array}$ & $(R)-4 \mathrm{c}^{\mathrm{a}}$ & 70.2 \\
\hline \multirow{3}{*}{$r a c-\mathbf{3 d}$} & \multirow{3}{*}{$\begin{array}{l}5 \mathrm{~min} \text { at } 50{ }^{\circ} \mathrm{C}, 50-200^{\circ} \mathrm{C} \\
10{ }^{\circ} \mathrm{C} \min ^{-1}\end{array}$} & $(R, S)-\mathbf{4} \mathbf{d}^{\mathrm{b}}$ & 7.1 \\
\hline & & $(S)-\mathbf{4} \mathbf{d}^{\mathrm{b}}$ & 14.5 \\
\hline & & $(R)-\mathbf{4} \mathbf{d}^{\mathrm{b}}$ & 14.6 \\
\hline \multirow{4}{*}{$r a c-\mathbf{3 e}$} & 5 min at $100^{\circ} \mathrm{C}, 100-142^{\circ} \mathrm{C}$ & $(R, S)-3 \mathrm{e}^{\mathrm{b}}$ & 1.3 \\
\hline & $\begin{array}{l}3{ }^{\circ} \mathrm{C} \min ^{-1}, 142-182{ }^{\circ} \mathrm{C} \\
10^{\circ} \mathrm{C} \mathrm{min}^{-1}\end{array}$ & $(R, S)-4 \mathrm{e}^{\mathrm{b}}$ & 17.6 \\
\hline & $100-160{ }^{\circ} \mathrm{C} 4{ }^{\circ} \mathrm{C} \mathrm{min}^{-1}$ & $(S)-4 \mathbf{e}^{\mathrm{a}}$ & 11.7 \\
\hline & $\begin{array}{l}160-180{ }^{\circ} \mathrm{C} 20^{\circ} \mathrm{C} \mathrm{min}^{-1}, \\
1 \mathrm{~min} \text { at } 180{ }^{\circ} \mathrm{C}\end{array}$ & $(R)-4 \mathrm{e}^{\mathrm{a}}$ & 11.9 \\
\hline
\end{tabular}

${ }^{a}$ Measured on Hydrodex $\beta-6$ TBDM column.

${ }^{\mathrm{b}}$ Measured on Hydrodex $\beta$-TBDAc column.

(Leiden, The Netherlands). N435-CaLB (Novozym ${ }^{\circledR} 435$, lipase B from $C$. antarctica, recombinant, expressed in Aspergillus niger, adsorbed on acrylic resin) was obtained from Sigma-Aldrich (Saint Louis, MO, USA).

\subsection{Analytical instrumentation and methods}

TLC was carried out using Kieselgel 60 F254 (Merck) sheets. Spots were visualized under UV light (Vilber Lourmat VL-6.LC, $254 \mathrm{~nm}$ ) or after treatment with $5 \%$ ethanolic phosphomolybdic acid solution and heating of the dried plates.

The NMR spectra were recorded in $\mathrm{CDCl}_{3}$ on a Bruker DRX-300 spectrometer operating at $300 \mathrm{MHz}$ for ${ }^{1} \mathrm{H}$ and $75 \mathrm{MHz}$ for ${ }^{13} \mathrm{C}$, and signals are given in ppm on the $\delta$ scale.

Optical rotation was measured on Perkin-Elmer 241 polarimeter at the D-line of sodium. The polarimeter was calibrated with measurements of both enantiomers of menthol.
The morphology of different immobilized enzyme preparations was analyzed by a JEOL JSM-5500LV scanning electron microscope (SEM) in high vacuum at accelerating voltage $25 \mathrm{kV}$. For better imaging, samples were coated with a gold nano-film layer by a vacuum nebulizer.

Elemental analysis was carried out on a VarioEL 15.5.6 instrument in CHN mode measuring two parallel of each sample.

Samples $(20 \mu \mathrm{L})$ from kinetic resolution reactions were diluted with ethanol $(1000 \mu \mathrm{L})$ and analyzed by two GC equipped with different columns, an Agilent 5890 GC was equipped with a Hydrodex $\beta$-TBDAc column (MachereyNagel; $25 \mathrm{~m} \times 0.25 \mathrm{~mm} \times 0.25 \mu \mathrm{m}$, heptakis-(2,3-di-Oacetyl-6-O-t-butyl-dimethylsilyl)- $\beta$-cyclodextrin) and an Agilent 4890 GC was equipped with a Hydrodex $\beta-6$ TBDM column (Macherey-Nagel; $25 \mathrm{~m} \times 0.25 \mathrm{~mm} \times 0.25 \mu \mathrm{m}$, heptakis-(2,3-di-O-methyl-6-O-t-butyl-dimethylsilyl)- $\beta$-cyclodextrin) [operation conditions for both instruments FID $\left(250^{\circ} \mathrm{C}\right)$, injector $\left(250^{\circ} \mathrm{C}\right), \mathrm{H}_{2}(12 \mathrm{psi}$, split ratio: $1: 50]$.

Conversion $(c)$, enantiomeric excess $(e e)$ and enantiomeric ratio $(E)$ were determined by GC. Enantiomeric ratio $(E)$ was calculated from $c$ and enantiomeric excess of the products $\left(e e_{(R) \text {-product }}\right.$ i.e. $e e_{(R)-2}$ or $\left.e e_{(R)-4 \mathrm{a}-\mathrm{e}}\right)[72]$. To characterize the productivity of the biocatalysts, the specific reaction rates in batch reactions $\left(r_{\text {batch }}\right)$ and in continuous-flow systems $\left(r_{\text {flow }}\right)$ were calculated accordingly [73].

\subsection{Characterization of modified silica supports}

Elemental analysis for supports (two parallel samples for each): M540: N: 3.747, C: $12.435 \mathrm{H}: 3.516$; M540-AE: N: 3.178, C: 16.480 H: 3.910; M540-BE: N: 3.438, C: 16.150 $\mathrm{H}:$ 4.039; M540-CE: N: 3.479, C: $17.170 \mathrm{H}: 4.052$; M540-DE: N: 3.280, C: 15.995 H: 3.966; M540-EE: $\mathrm{N}: 3.296, \mathrm{C}: 17.765 \mathrm{H}: 4.151$; M540-FE: N: 3.230, C: 18.340 H: 4.321; M540-GA: N: 3.421, C: 17.040 H: 3.819.

\subsection{Immobilization of $\mathrm{CaLB}$ on different supports}

Aldehyde-modification: M540-GA was prepared by reacting of M540 silica (1000 mg) in the solution of glutaraldehyde (592 $\mathrm{mg}, 5.93 \mathrm{mmol})$ and ethanol $(16 \mathrm{~mL})$ in shaken flask $(350 \mathrm{rpm})$ at $60{ }^{\circ} \mathrm{C}$ for $24 \mathrm{~h}$. The M540-GA was filtered off from the reaction mixture, washed with ethanol $(2 \times 20 \mathrm{~mL})$ and dried in vacuum (RT, $24 \mathrm{~h})$. Then M540-GA was afforded as an off-white solid.

Immobilization: To a solution of $\mathrm{CaLB}(150.0 \mathrm{mg})$ in phosphate buffer $(37.5 \mathrm{~mL}, 100 \mathrm{mM}, \mathrm{pH}=7.5$, ionic strength controlled with $\mathrm{NaCl}$ ) was added to the carrier (CV T2-150, M540, M540-GA, M540-AE, M540-BE, 
M540-CE, M540-DE, M540-EE or M540-FE: $750.0 \mathrm{mg}$ ) and the resulted mixture was shaken at $350 \mathrm{rpm}$ at RT for $24 \mathrm{~h}$. The immobilized $\mathrm{Ca}$ LB biocatalyst was filtered off on glass filter (G4), washed with phosphate buffer $(2 \times 20 \mathrm{~mL}$, $100 \mathrm{mM}, \mathrm{pH}=7.5)$, distilled water $(2 \times 40 \mathrm{~mL})$, propan-2-ol $(2 \times 20 \mathrm{~mL})$ and dried at RT $(2 \mathrm{~h})$ and stored at $4{ }^{\circ} \mathrm{C}$ (Fig. 1).

Removal of the non-covalently bound proteins: To a solution of Triton X-100 (7 mg, $6.5 \mu \mathrm{L})$ in phosphate buffer $(7 \mathrm{~mL}, 100 \mathrm{mM}, \mathrm{pH}=7.5$, ionic strength controlled with $\mathrm{NaCl}$ ) was added the immobilized $\mathrm{CaLB}$ biocatalyst (CV T2-150-CaLB, M540-CaLB, M540-GA-CaLB, M540-A-CaLB, M540-B-CaLB, M540-C-CaLB, M540D-CaLB, M540-E-CaLB or M540-F-CaLB: $200.0 \mathrm{mg}$ ). The mixture was shaken for $2 \mathrm{~h}$ (350 rpm, RT). The suspension

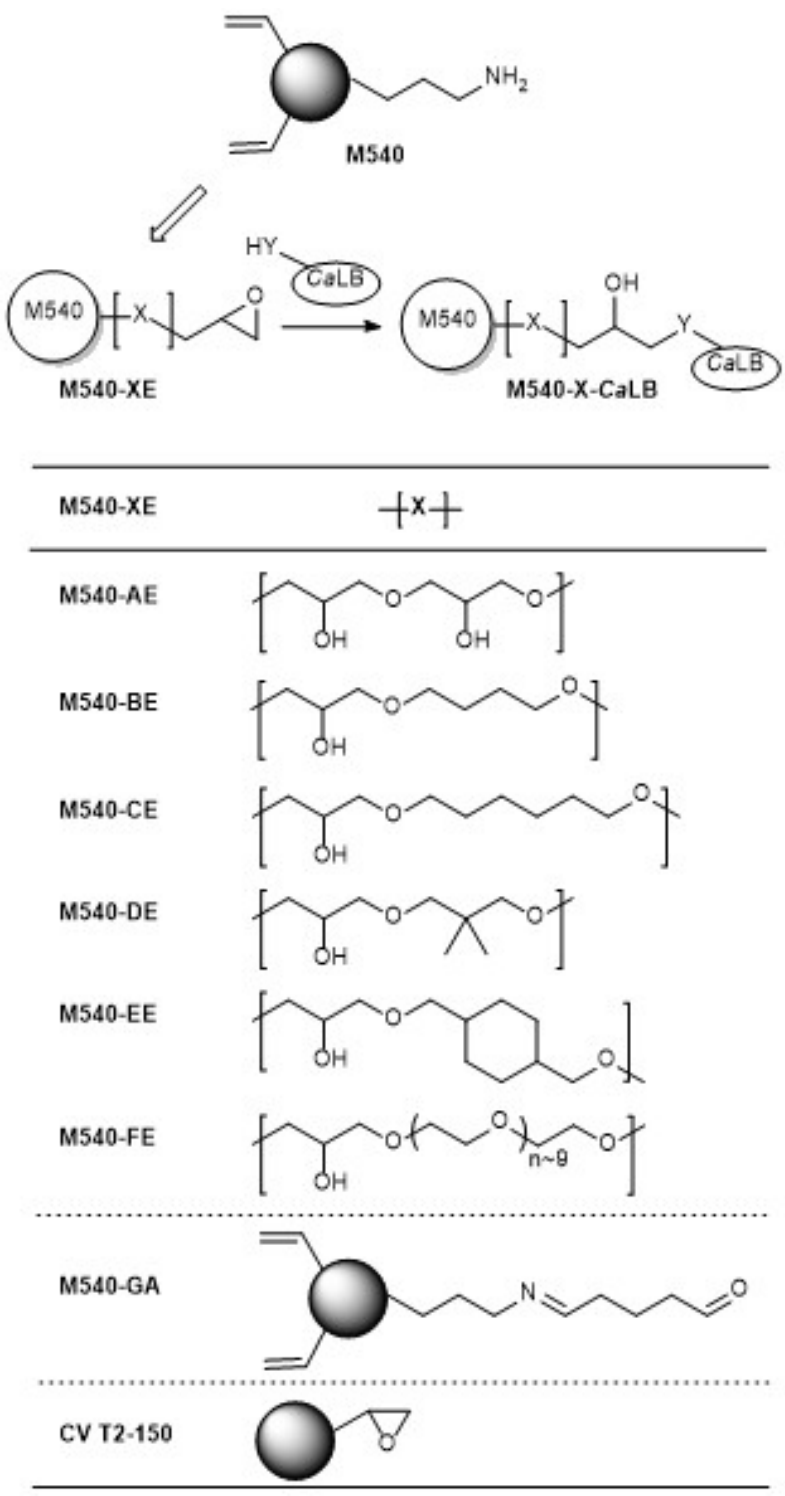

Fig. 1 Immobilization of $C a \mathrm{LB}$ on epoxy-functionalized spherical mesoporous silica carriers M540-XE was centrifuged at $3500 \mathrm{rpm}$ for $5 \mathrm{~min}$ at $4{ }^{\circ} \mathrm{C}$ (Hermle $\mathrm{Z}$ $400 \mathrm{~K})$. After the supernatant was decanted, distilled water $(15 \mathrm{~mL})$ was added to precipitated biocatalyst and shaken for $10 \mathrm{~min}$ (350 rpm, RT). This method was repeated until the supernatant liquid turned foamless (ca. 12 cycles).

\subsection{Kinetic resolution of racemic 1 phenyethanol $\mathrm{rac}-1$ in batch mode}

Into a screw cap reaction vial were added a mixture $(2.0 \mathrm{~mL})$ of hexane and MTBE (volume ration 2:1), rac-1 $(100 \mu \mathrm{L}$, $0.393 \mathrm{M}$ ), vinyl acetate (2.6 equiv., $200 \mu \mathrm{L}, 1.022 \mathrm{M}$ ) and the immobilized $\mathrm{CaLB}$ biocatalyst (M540-CaLB, CV T2-150-CaLB, M540-GA-CaLB, M540-A-CaLB, M540B-CaLB, M540-C-CaLB, M540-D-CaLB, M540-E-CaLB or M540-F-CaLB: $25.0 \mathrm{mg}$ ). The reaction mixture was shaken $(350 \mathrm{rpm})$ at $30{ }^{\circ} \mathrm{C}$. The reactions were monitored by taking samples and analyzed by TLC and GC.

\subsection{Kinetic resolution of racemic amines rac-3a-e in batch mode}

Into a screw cap vial were added a solution of rac-3a-e (1.5 mmol) and isopropyl 2-ethoxyacetate (0.6 equiv.: $0.9 \mathrm{mmol}, 132 \mathrm{mg}, 130 \mu \mathrm{L})$ in dry toluene $(2.0 \mathrm{~mL})$ and the M540-F-CaLB (50.0 mg) biocatalyst. The reaction mixture was shaken $(350 \mathrm{rpm})$ at $60{ }^{\circ} \mathrm{C}$ and monitored by taking samples several times $(0.5,1,1.5,2,2.5,3,3.5$ and $4 \mathrm{~h})$ and analyzed by TLC and GC.

The batch mode kinetic resolution reactions of racemic amines rac-3a-e were stopped after $4 \mathrm{~h}$ and biocatalyst was filtered off on glass filter (G4) and washed with toluene $(2 \times 5 \mathrm{~mL})$ and ethyl acetate $(2 \times 5 \mathrm{~mL})$. Hydrochloric acid $(10 \mathrm{~mL}, 20 \%)$ was added to the combined organic phase (filtrate and washing solvents) and mixture was stirred for $20 \mathrm{~min}$ at $\mathrm{rt}$. After separating the phases, the aqueous phase was extracted with $\mathrm{CH}_{2} \mathrm{Cl}_{2}(2 \times 10 \mathrm{~mL})$ and the organic phases were unified and washed with saturated brine $(2 \times 10 \mathrm{~mL})$ and dried over $\mathrm{Na}_{2} \mathrm{SO}_{4}$. The solvents and other volatiles were subsequently removed in vacuum and $(R)$-2-ethoxyacetamides $(R)$-4a-e were afforded as light yellow liquids.

(R)-2-Ethoxy-N-(1-phenylethyl)acetamide (R)-4a: Yield: $150 \mathrm{mg}(48 \%) ; e e_{(R)-4 \mathrm{a}}=99.8 \%$ (GC on Hydrodex $\beta-6$ TBDM column) [47].

(R)-2-Ethoxy-N-(4-phenylbutan-2-yl)acetamide $(R)$-4b: Yield: $164 \mathrm{mg}(47 \%) ; \mathrm{R}_{\mathrm{f}}\left(5 \% \mathrm{CH}_{3} \mathrm{OH} / \mathrm{CH}_{2} \mathrm{Cl}_{2}\right)$ $0.86 ;[\alpha]_{\mathrm{D}}{ }^{20}+18.6\left(\mathrm{c} 1, \mathrm{CH}_{2} \mathrm{Cl}_{2}\right) ; e e_{(R)-4 \mathrm{~b}}=99.2 \%(\mathrm{GC}$ on Hydrodex $\beta-6$ TBDM column); $\mathrm{d}_{\mathrm{H}}\left(300 \mathrm{MHz}, \mathrm{CDCl}_{3}\right)$ : $1.19\left(3 \mathrm{H}, \mathrm{d}, J=6.6, \mathrm{CH}_{3}\right) ; 1.22\left(3 \mathrm{H}, \mathrm{t}, J=7.0, \mathrm{CH}_{3}\right)$; 
1.73-1.82 (2H, m, $\left.\mathrm{CH}_{2}\right) ; 2.64\left(2 \mathrm{H}, \mathrm{t}, \mathrm{CH}_{2}\right) ; 3.54\left(2 \mathrm{H}, \mathrm{q}, J_{1}\right.$ $\left.=7.0, \mathrm{CH}_{2}\right) ; 3.88\left(2 \mathrm{H}, \mathrm{s}, \mathrm{CH}_{2}\right) ; 4.03-4.14(1 \mathrm{H}, \mathrm{m}, \mathrm{CH}) ; 6.37$ $(1 \mathrm{H}, \mathrm{s}, \mathrm{NH}) ; 7.13-7.28(5 \mathrm{H}, \mathrm{m}, \mathrm{ArH}) ; \mathrm{d}_{\mathrm{C}}\left(75 \mathrm{MHz}, \mathrm{CDCl}_{3}\right)$ 169.15, 141.71, 128.44, 128.34, 125.93, 69.98, 67.09, 44.54, $38.70,32.54,21.07,15.08 ; \mathrm{n}_{\max }$ (liquid film): 2971, 1646, 1534, 1453, 1113, 749, 698, $518 \mathrm{~cm}^{-1}$.

(R)-2-Ethoxy-N-(1, 2, 3, 4-tetrahydronaphtalen-1-yl) acetamide (R)-4c: Yield: $167 \mathrm{mg}(47 \%) ; \mathrm{R}_{\mathrm{f}}\left(5 \% \mathrm{CH}_{3} \mathrm{OH} /\right.$ $\left.\mathrm{CH}_{2} \mathrm{Cl}_{2}\right)$ 0.91; $[\alpha]_{\mathrm{D}}{ }^{20}+41.7\left(c 1, \mathrm{CH}_{2} \mathrm{Cl}_{2}\right) ; e e_{(R)-4 \mathrm{c}}=98.7 \%(\mathrm{GC}$ on Hydrodex $\beta$-TBDM column); $\mathrm{d}_{\mathrm{H}}\left(300 \mathrm{MHz}, \mathrm{CDCl}_{3}\right)$ : 1.01$1.33\left(3 \mathrm{H}, \mathrm{m}, \mathrm{CH}_{3}\right) ; 1.72-1.94\left(2 \mathrm{H}, \mathrm{m}, \mathrm{CH}_{2}\right) ; 1.96-2.24(2 \mathrm{H}$, $\left.\mathrm{m}, \mathrm{CH}_{2}\right) ; 2.68-2.95\left(2 \mathrm{H}, \mathrm{m}, \mathrm{CH}_{2}\right) ; 3.57\left(2 \mathrm{H}, \mathrm{q}, J=7.0, \mathrm{CH}_{2}\right)$; $4.00\left(2 \mathrm{H}, \mathrm{s}, \mathrm{CH}_{2}\right) ; 5.16-5.36(1 \mathrm{H}, \mathrm{m}, \mathrm{CH}) ; 6.83(1 \mathrm{H}, \mathrm{d}, J=7.4$, $\mathrm{NH})$; 7.04-7.38 (4H, m, ArH); d $\mathrm{C}_{\mathrm{C}}\left(75 \mathrm{MHz}, \mathrm{CDCl}_{3}\right)$ 169.29, 137.62, 136.63, 129.21, 128.54, 127.30, 126.31, 70.02, 67.14, 46.88, 30.37, 29.29, 20.24, 15.03; $\mathrm{n}_{\max }$ (liquid film): 3412, $3306,2931,1664,1513,1113,746,741,549 \mathrm{~cm}^{-1}$.

(R)-2-Ethoxy-N-(1-methoxypropan-2-yl)acetamide (R)-4d: Yield: $110 \mathrm{mg}(42 \%) ; \mathrm{R}_{\mathrm{f}}\left(5 \% \mathrm{CH}_{3} \mathrm{OH} / \mathrm{CH}_{2} \mathrm{Cl}_{2}\right)$ $0.85 ;[\alpha]_{\mathrm{D}}^{20}+11.0\left(c 1, \mathrm{CH}_{2} \mathrm{Cl}_{2}\right) ; e e_{(R)-4 \mathrm{~d}}=96.5 \%(\mathrm{GC}$ on Hydrodex $\beta$-TBDAc column); $\mathrm{d}_{\mathrm{H}}\left(300 \mathrm{MHz} \mathrm{CDCl}_{3}\right): 1.19$ $\left(1 \mathrm{H}, \mathrm{d}, J=6.8, \mathrm{CH}_{3}\right) ; 1.22\left(3 \mathrm{H}, \mathrm{t}, J=7.0, \mathrm{CH}_{3}\right) ; 3.35(3 \mathrm{H}$, $\left.\mathrm{s}, \mathrm{CH}_{3}\right) ; 3.36\left(2 \mathrm{H}, \mathrm{d}, J=4.5, \mathrm{CH}_{2}\right) ; 3.54(2 \mathrm{H}, \mathrm{q}, J=7.0$, $\left.\mathrm{CH}_{2}\right) ; 3.89\left(2 \mathrm{H}, \mathrm{s}, \mathrm{CH}_{2}\right) ; 4.07-4.27\left(1 \mathrm{H}, \mathrm{m}, J_{1}=8.7, J_{2}=\right.$ $\left.6.8, J_{3}=4.5, \mathrm{CH}\right), 6.55-6.77(1 \mathrm{H}, \mathrm{m}, \mathrm{NH}) ; \mathrm{d}_{\mathrm{C}}(75 \mathrm{MHz}$, $\left.\mathrm{CDCl}_{3}\right)$ 169.36, 75.54, 70.01, 67.10, 59.08, 44.21, 17.64, 15.03; $\mathrm{n}_{\max }$ (liquid film): 3418, 3305, 2976, 2878, 1663, $1523,1449,1106,569 \mathrm{~cm}^{-1}$.

(R)-2-Ethoxy-N-(heptan-2-yl)acetamide (R)-4e: Yield: $139 \mathrm{mg}(46 \%) ; e e_{(R)-4 \mathrm{e}}=96.5 \%$ (GC on Hydrodex $\beta-6$ TBDM column) [74].

\subsection{Recyclability of immobilized $\mathrm{CaLB}$ biocatalysts}

Into a screw-capped flask $(20 \mathrm{~mL})$ were added the immobilized $\mathrm{CaLB}$ biocatalyst (M540-C-CaLB, M540-DCaLB, M540-F-CaLB, CV T2 150-CaLB, N435-CaLB: $200.0 \mathrm{mg})$ and a solution of $\mathrm{rac}-\mathbf{1}(800 \mu \mathrm{L}, 0.393 \mathrm{M})$, vinyl acetate (2.6 equiv., $1600 \mu \mathrm{L}, 1.022 \mathrm{M})$ in a mixture of hexane and MTBE (2:1 volume ratio final volume 16 $\mathrm{mL})$. The reaction mixture was shaken $(350 \mathrm{rpm})$ at $30^{\circ} \mathrm{C}$ and the reaction was stopped after $30 \mathrm{~min}$, sample was taken and analyzed by TLC and GC. The biocatalyst was filtered off on a glass filter $(\mathrm{G} 4)$, washed with hexane $(1 \times$ $20 \mathrm{~mL})$, MTBE $(2 \times 20 \mathrm{~mL})$ and hexane $(1 \times 20 \mathrm{~mL})$ and dried at RT for $30 \mathrm{~min}$. The recovered biocatalyst was re-used in the next cycle under the same conditions (and keeping the substrate / biocatalyst weight ratio constant) in 10 cycles.

\subsection{Immobilized $C a \mathrm{LB}$ packed-bed columns}

Immobilized $\mathrm{CaLB}$ biocatalyst (M540-C-CaLB, M540D- $C a \mathrm{LB}, \mathrm{M} 540-\mathrm{F}-\mathrm{Ca} \mathrm{LB}$ ) was packed into stainless steel columns (stainless steel, inner diameter: $4 \mathrm{~mm}$; total length: $70 \mathrm{~mm}$; packed length: $65 \mathrm{~mm}$; inner volume: $0.816 \mathrm{~mL}$ ) according to the filling process of ThalesNano Inc. The columns were sealed by silver metal [Sterlitech Silver Membrane from Sigma Aldrich, Z623237, pore size $0.45 \mu \mathrm{m}$; pure metallic silver, $99.97 \%$ with no extractable or detectable contaminants] and PTFE [Whatman ${ }^{\circledR}$ Sigma Aldrich, WHA10411311, pore size $0.45 \mu \mathrm{m}$ ] filter membranes and PTFE sealing. Filling weights of the immobilized $\mathrm{CaLB}$ biocatalysts in the packed-bed bioreactors were determined by using analytical balance (M540-C-CaLB: $220 \pm 3$ mg; M540-D-CaLB: $230 \pm 5$ mg; M540-F-CaLB: $240 \pm 6 \mathrm{mg}$ ).

\subsection{Kinetic resolution of alcohol rac-1 and amines rac-3a-e in continuous flow mode}

Kinetic resolutions in the packed-bed bioreactors filled with the $\mathrm{CaLB}$ biocatalysts in continuous-flow mode were performed in a laboratory scale flow reactor which comprised a HPLC pump (Knauer, Azura 4.1S), packedbed column filled with $\mathrm{CaLB}$ biocatalyst within an in house made thermostated aluminum metal block holder with precise temperature control (Lauda, Alpha RA8). Before usage, the actual $C a$ LB-filled column was washed with the corresponding solvent (for rac-1: 2:1 mixture of hexane and MTBE for 1 phenylethanol; for rac-3a-e: toluene; $0.5 \mathrm{~mL} \mathrm{~min}^{-1}, 30 \mathrm{~min}$ ). At each set of reaction parameters (temperature, substrate concentration, flow rate), samples were analyzed by GC every $10 \mathrm{~min}$ up to $40 \mathrm{~min}$ after the start of the experiment. After the stationary mode of operation has been established (40 min after the start of the experiment) samples were collected $(20 \mu \mathrm{L}$ sample was diluted with ethanol to $1 \mathrm{~mL}$ ) and analyzed by TLC and GC. After a series of experiments, the actual CaLBfilled column was washed with the corresponding solvent $\left(0.5 \mathrm{~mL} \mathrm{~min}{ }^{-1}, 30 \mathrm{~min}\right)$ and stored in refrigerator $\left(4^{\circ} \mathrm{C}\right)$.

\subsubsection{Continuous-flow mode kinetic resolution of 1-phenylethanol rac-1 in different concentrations}

A solution containing 1-phenylethanol rac-1 at different concentrations $\left(1,5,10,24,48,86 \mathrm{mg} \mathrm{mL}^{-1}\right.$ i.e. 0.008 , $0.041,0.082,0.196,0.393,0.704 \mathrm{M}$ ) in a $2: 1$ mixture of hexane and MTBE supplemented with vinyl acetate (2.6 equiv.) was pumped through the $\mathrm{CaLB}$-filled columns thermostated to $30{ }^{\circ} \mathrm{C}$ at a flow rate of $0.20 \mathrm{~mL} \mathrm{~min}^{-1}$. 


\subsubsection{Continuous-flow mode kinetic resolution of} 1-phenylethanol rac-1 at various temperatures The solution of 1-phenylethanol rac-1 $\left(0.704 \mathrm{M}, 86 \mathrm{mg} \mathrm{mL}^{-1}\right)$ and vinyl acetate $(2.6$ equiv., $1.830 \mathrm{M})$ in a $2: 1$ mixture of hexane and MTBE was pumped through the $\mathrm{CaLB}$-filled column thermostated to various temperatures $\left(0-90{ }^{\circ} \mathrm{C}\right.$, in $15^{\circ} \mathrm{C}$ steps) at a flow rate of $0.20 \mathrm{~mL} \mathrm{~min}{ }^{-1}$.

Continuous-flow mode kinetic resolution of 1 phenylethanol rac-1 with elongated operation time: The solution of 1-phenylethanol rac-1 (0.393 M, i.e. $\left.48 \mathrm{mg} \mathrm{mL}^{-1}\right)$ and vinyl acetate (2.6 equiv., $1.022 \mathrm{M}$ ) in a 2:1 mixture of hexane and MTBE was pumped through an M540-F-CaLBfilled column at a flow rate of $0.10 \mathrm{~mL} \mathrm{~min}^{-1}$ thermostated to subsequently increasing temperatures $\left(60^{\circ} \mathrm{C}, 75^{\circ} \mathrm{C}\right.$ or $\left.90^{\circ} \mathrm{C}\right)$. Samples were collected after different operating times $(0.5,1,2,3,4,5,6,10,19,20,21,22,23,24 \mathrm{~h})$ and analyzed by TLC and GC.

\subsubsection{Continuous-flow mode kinetic resolution of racemic amines rac-3a-e}

The solution of racemic amine (rac-3a-e, $0.646 \mathrm{M})$ and isopropyl 2-ethoxyacetate ( 0.6 equiv., $0.388 \mathrm{mmol}$ ) in dry toluene was pumped through the M540-F-CaLB-filled column

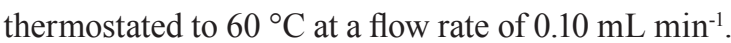

\section{Results and discussion}

\subsection{Covalent immobilization of lipase B from Candida antarctica onto hollow silica microspheres and kinetic resolution of 1 phenylethanol rac-1}

By the aid of amine groups on surface of M540 hollow silica microspheres as support, six bisepoxide-activated carriers (M540-A-F) were prepared having different length and hydrophobicity in the spacer region of the activating bisepoxide (Fig. 1). The carriers were characterized by FT-IR, elemental analysis and scanning electron microscopy (SEM). As reference, the unmodified M540 was used to compare adsorptive immobilization and the glutaraldehyde (GA)-activated form of M540 (M540 GA) was also investigated as further reference for covalent binding. For comparison, the commercially available epoxy-functionalized polyacrylic carrier CV T2-150 (particle size 300-700 $\mu \mathrm{m}$ ) was also included in immobilization experiments. With the three reference carriers and the six bisepoxide-activated M540 carriers in hand, immobilization of $\mathrm{CaLB}$ was performed using lyophilized form of $\mathrm{CaLB}$ in phosphate buffer (100 mM, pH 7.5) at room temperature (24 h).

To distinguish between the catalytic activity of the physically adsorbed and the covalently bound enzymes, a post-treatment with Triton X 100 non-ionic detergent solution was performed after the immobilization step which could remove those enzyme molecules which were only adsorbed by physical interactions onto the surface.

Catalytic performance of the resulted biocatalysts was tested in kinetic resolution (KR) of racemic 1-phenylethanol rac-1 in batch mode (Fig. 2) before and after the Triton $\mathrm{X}-100$ wash to provide information of enzyme immobilization efficiency (i.e. washing resistance) of supports (Table 2).

As it was expected, the $C a \mathrm{LB}$ attached to unmodified M540 carrier retained the least activity after post-treatment (Table 2, Entry 1, $39 \%$ ) while the covalently fixed biocatalysts retained at least $83 \%$ residual activity

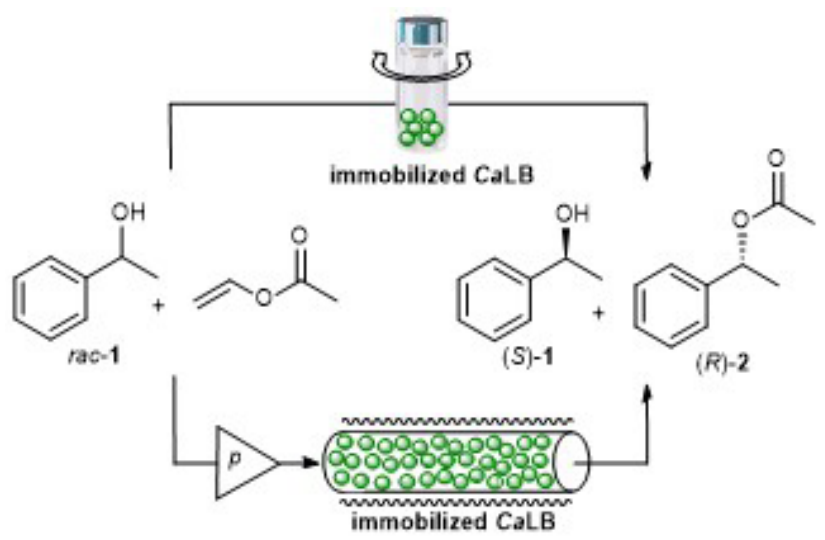

Fig. 2 Immobilized $C a \mathrm{LB}$ in kinetic resolutions (KRs) of racemic 1-phenylethanol (rac-1) in batch mode using shaken flasks and in continuous-flow mode using packed-bed microreactors

Table 2 Kinetic resolution of 1-phenylethanol rac-1 catalyzed by variously immobilized $\mathrm{Ca}$ LB biocatalysts in batch mode

\begin{tabular}{llcccc}
\hline No. & $\begin{array}{l}\text { Carrier for } \\
\text { CaLB }^{\mathrm{a}, \mathrm{b}}\end{array}$ & $\begin{array}{c}\text { Conv. }^{\mathrm{c}} \\
{[\%]}\end{array}$ & $\begin{array}{c}e e_{(R)-2 \mathrm{~d}} \\
{[\%]}\end{array}$ & $\begin{array}{c}E^{\mathrm{c}} \\
{[-]}\end{array}$ & $\begin{array}{c}\text { Washing } \\
\text { resistance }^{\mathrm{d}}[\%]\end{array}$ \\
\hline 1 & M540 & 2 & 97.9 & 95 & 39 \\
2 & M540-GA & 5 & 98.6 & 145 & 88 \\
3 & CV T2-150 & 11 & 98.8 & 191 & 92 \\
4 & M540-AE & 11 & 98.7 & 172 & 152 \\
5 & M540-BE & 15 & 98.6 & 175 & 98 \\
6 & M540-CE & 16 & 98.8 & 194 & 83 \\
7 & M540-DE & 17 & 98.9 & $>200$ & 101 \\
8 & M540-EE & 15 & 98.7 & 175 & 89 \\
9 & M540-FE & 19 & 98.9 & $>200$ & 94 \\
\hline
\end{tabular}

${ }^{a}$ Reaction conditions: rac-1 $(100 \mu \mathrm{L}, 0.393 \mathrm{M})$, vinyl acetate (2.6 equiv., $200 \mu \mathrm{L}, 1.022 \mathrm{M})$ in hexane and $\mathrm{MTBE}(2: 1$ volume ratio, $2.0 \mathrm{~mL}$ ), enzyme preparations $(25.0 \mathrm{mg})$, reaction time $30 \mathrm{~min}$ at $30{ }^{\circ} \mathrm{C}$. ${ }^{\text {b }}$ CaLB preparations: (1) adsorbed on M540 support; (2) bound to M540 support after glutaraldehyde treatment; (3) bound to CV T2-150 support; (4-9) bound to M540-XE supports.

${ }^{c}$ Determined by GC.

${ }^{\mathrm{d}}$ Washing resistance $(\%)$ = activity of biocatalyst washed with Triton X-100 / activity of the preparation before Triton X-100 washing $\times 100$ 
(Table 2, Entries 2-9) after detergent washing. This fact strongly support that the non-activated M540 carrier could not establish covalent attachment but only ionic and physical interactions to fix enzyme molecules on the surface.

In the case of M540-A-CaLB, an interesting effect was observed. Instead of decreasing the enzyme activity upon Triton X-100 washing a $52 \%$ activation was observed. This difference could be explained by assuming activation due to the bioimprinting effect of surfactant [33, 75-77]. Compared to the adsorptive CaLB-M540 preparation, catalytic performance of the GA-activated biocatalyst (M540GA- $C a \mathrm{LB}$ ) was three times higher while conversion values of epoxy-activated M540-X-CaLB (X = A-F) biocatalysts were at least ten times higher in KR of rac-1 indicating the beneficial nature of bisepoxide-activation over the widely used GA-derivatization or adsorptive immobilization. These results could be attributed to the enhanced covalent bond formation capability of epoxy containing supports compared to aldehyde-activated carriers under mild conditions (approximately neutral pH, RT) [54].

Moreover, inspection of the length and lipophilicity of epoxy-spacers (M540-A-F) revealed that flexibility and hydrophobicity of sidechain affected the immobilization efficiency of the bisepoxide-activated carriers. This could be related to the first event of immobilization on epoxy supports, since a physical adsorption of enzymes onto the surface always preceded the covalent bond formation by epoxide ring-openings. Analyzing the activities of covalently attached $\mathrm{CaLB}$ on pre-activated carriers indicated the role of functionalization and the quality of spacers, where the aldehyde- and any epoxy-modification exceeded the catalytic performance of untreated silica carrier M540. Amongst the investigated bisepoxide-activated carriers, M540-FE with a poly(ethylene glycol) spacer proved to be the most suitable to immobilize $C a \mathrm{LB}$ in active form [78]. In addition, the enantiomeric purity of formed product $(R)-1$ phenylethylacetate $(R)-\mathbf{2}$ was excellent $\left(e e_{(R)-2} \geq 98.6 \%\right)$ when KR was catalyzed by covalently immobilized forms of $\mathrm{CaLB}$.

\subsection{Continuous-flow mode kinetic resolution of} 1-phenylethanol rac-1 catalyzed by covalently attached silica $\mathrm{CaLB}$ preparations - substrate concentration and temperature effects

Immobilization of enzymes plays an indispensable and crucial role in the application of biocatalysts with natural origin in batch and continuous-flow bioreactors [45-47, 79]. The operation temperature could substantially influence the productivity and selectivity of lipase-catalyzed hydrolytic and acylation reactions of chiral and non-chiral substrates [73, 80]. Accordingly, two series of experiments were performed to study the effect $i$ ) of substrate concentration rac-1 (1-86 $\left.\mathrm{mg} \mathrm{mL}^{-1}\right)$ and ii) of reaction temperature $\left(0-90{ }^{\circ} \mathrm{C}\right.$, in $15{ }^{\circ} \mathrm{C}$ steps $)$. The reactions were carried out in heat and pressure resistant stainless steel packedbed columns operated within a lab reactor system with precise temperature and flow rate control. The three most effective $\mathrm{CaLB}$ preparations immobilized covalently onto hollow silica microspheres (M540-C-CaLB, M540-D, M540-F- $C a$ LB $C a \mathrm{LB}$ ) were selected as biocatalysts in packed-bed columns for the continuous flow kinetic resolution studies (Fig. 2).

During the substrate concentration dependence study, the solution of substrate rac-1 in different $\left(1-86 \mathrm{mg} \mathrm{mL}^{-1}\right)$ and the vinyl acetate acylating agent in hexane and MTBE was pumped through the CaLB-filled columns thermostated to $30{ }^{\circ} \mathrm{C}$ at a constant flow rate $\left(0.20 \mathrm{~mL} \mathrm{~min}^{-1}\right)$.

The productivity, characterized by the specific reaction rate $\left(r_{\mathrm{f}}, \mu \mathrm{mol} \mathrm{min}^{-1} \mathrm{~g}^{-1}\right)$ of enzyme preparations was investigated as a function of substrate concentration (Fig. 3, panel A). The specific reaction rates $\left(r_{\mathrm{f}}\right)$ with the three selected, covalently immobilized $\mathrm{CaLB}$ biocatalysts were quite similar at lower concentrations (1-48 $\mathrm{mg} \mathrm{mL}^{-1}$ ), while in higher concentration range $\left(48-86 \mathrm{mg} \mathrm{mL}^{-1}\right)$, the M540-F-CaLB surpassed the performance of the two other selected $\mathrm{CaLB}$ forms, similarly as in case of batch mode KRs. In addition, the $e e_{(R)-2}$ values of formed $(R)-1-$ phenylethyl acetate $(R)-2$ (Fig. 3, panel B) were significantly higher in continuous-flow mode $\left(e e_{(R)-2}=99.2-99.4 \%\right)$ than in batch mode $\left(e e_{(R)-2}=98.8-98.9 \%\right)$, due to the shorter contact time between the biocatalyst and the racemic substrate. The highly enantioselective KR process with these $\mathrm{CaLB}$ preparations immobilized covalently onto hollow silica microspheres also showed the prosperous technological benefit of continuous-flows systems over the batch reactors.

Next, the thermal behavior of immobilized $C a \mathrm{LB}$ preparations on epoxy-activated carriers (M540-C-, M540-D-, M540-F-CaLB) was investigated to gain information about their catalytic performance at different temperatures. For these series of experiments, the former system (used for the substrate concentration dependence studies) was applied at the highest substrate concentration $\left(86 \mathrm{mg} \mathrm{mL}^{-1}\right)$, while the temperature was varied between $0-90{ }^{\circ} \mathrm{C}$ in $15^{\circ} \mathrm{C}$ steps at a constant flow rate $\left(0.20 \mathrm{~mL} \mathrm{~min}^{-1}\right)$.

First, as a function of temperature, the productivity of enzyme preparations $\left(r_{\mathrm{f}}\right)$ was monitored (Fig. 3c, panel C). 

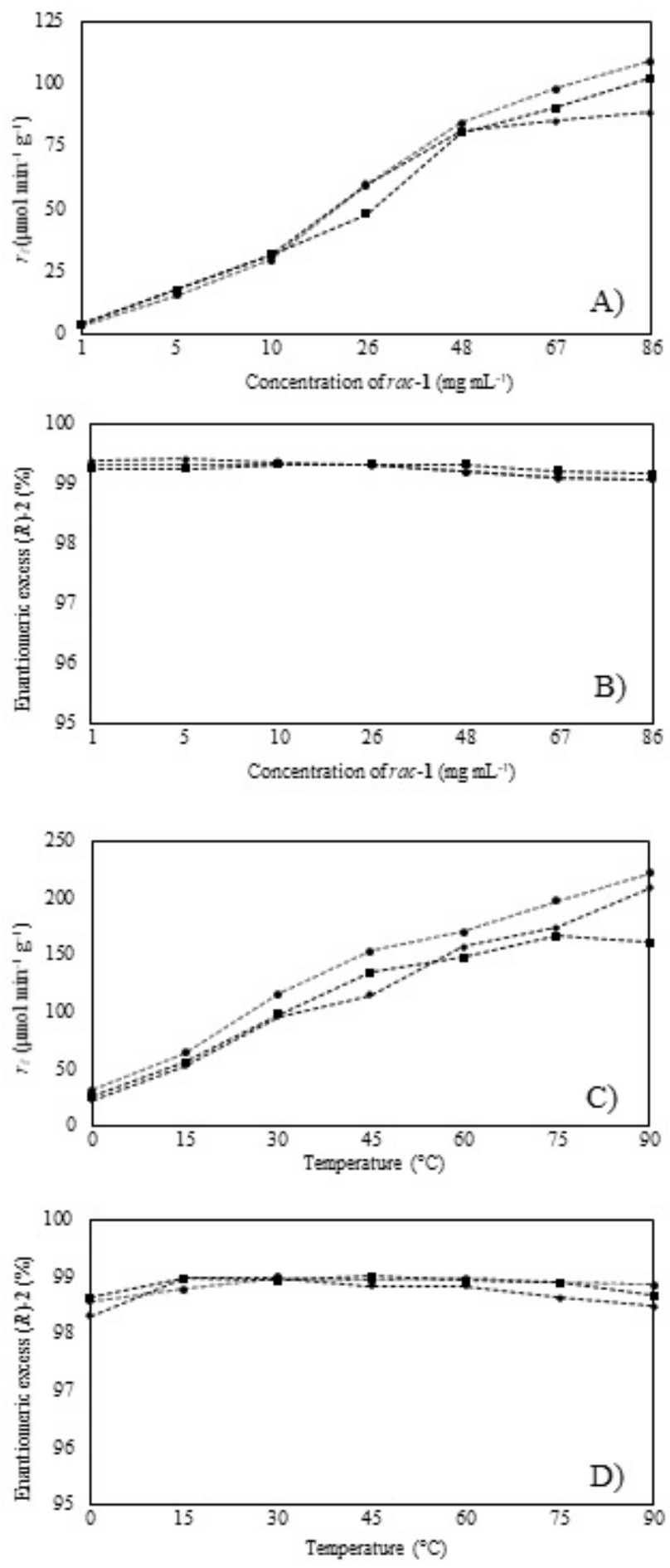

Fig. 3 Continuous-flow kinetic resolution of 1-phenylethanol rac-1 catalyzed by three covalently immobilized $\mathrm{CaLB}$ biocatalysts: M540-C-CaLB (•), M540-D-CaLB (•) and M540-F-CaLB (•) at a flow rate of $0.20 \mathrm{~mL} \mathrm{~min}^{-1}$ using 2.6 equiv. vinyl acetate as acyl donor. Temperature in experiments (A) and (B) was $30^{\circ} \mathrm{C}$, concentration of rac-1 in experiments (C) and (D) was $86 \mathrm{mg} \mathrm{mL}^{-1}$ (i.e. $0.704 \mathrm{M}$ ).

As shown, the productivity-temperature curves in the lower temperature range $\left(0-45{ }^{\circ} \mathrm{C}\right)$ were quasi-linear in case of all the three selected $\mathrm{CaLB}$ preparations. In the higher temperature range $\left(45-90^{\circ} \mathrm{C}\right)$, however, the M540D-CaLB started to lose its activity and the productivitytemperature curve descended, while the M540-C-CaLB and M540-F-CaLB biocatalysts kept the linearly increasing tendency until $90^{\circ} \mathrm{C}$.

The influence of the temperature on the enantiomeric excess of the product $\left(e e_{(R)-2}\right)$ was also studied. It was apparent, that the overall shapes of the $e e_{(R)-2}$-temperature curves were quite similar with all the three $\mathrm{CaLB}$ preparations (Fig. 3, panel D) in the entire temperature range. After a short ascending region $\left(0-30{ }^{\circ} \mathrm{C}\right)$, local maxima were found by the $e e_{(R)-2}$ values between $30^{\circ} \mathrm{C}$ and $60{ }^{\circ} \mathrm{C}$ after which a slightly decreasing region was detected at elevated temperature $\left(>60{ }^{\circ} \mathrm{C}\right)$. According to these results, the most productive and selective operating temperature was at around $60{ }^{\circ} \mathrm{C}$.

\subsection{Kinetic resolution of racemic amines rac-3a-e with M540-F-CaLB}

After the catalytic performance and stability of $\mathrm{CaLB}$ bound to hollow silica microspheres were investigated in KR of alcohol rac-1, the best performing M540-F$\mathrm{CaLB}$ was further studied in KRs of five racemic amines rac-3a-e. Isopropyl 2-ethoxyacetate as acylating agent in KR of 1-phenylethylamine rac-3a [47] surpassed the productivity and selectivity of the previously best performing isopropyl 2-methoxyacetate [81] in terms of both productivity (2-3-fold) and selectivity $\left(e e_{(R)-4 a} \geq 98.3 \%\right)$. Accordingly, this acyl donor was selected for our study on KRs of racemic amines rac-3a-e performed in batch and continuous-flow bioreactors at $60{ }^{\circ} \mathrm{C}$ (Fig. 4) which was the thermal optimum of M540-F-CaLB with alcohol rac-1. As the rate of product formation is not a linear function of conversion [73], productivity (i.e. the specific reaction rate, $r$ ) of a continuous-flow reaction $\left(r_{\mathrm{f}}\right)$ and of the corresponding one in batch mode $\left(r_{\mathrm{b}}\right)$ were compared at similar degrees of conversions ( $>49 \%$ ). As shown in Table 3 , in KRs of amines 1.5-2 higher $r_{\text {flow }}$ values could be achieved in packed-bed microreactors as compared to the $r_{\text {batch }}$ values in batch system (in accordance with the known benefit of continuous-flow systems compared to batch reactors [82]).

\subsection{Reusability, mechanical and thermal stability of covalently immobilized $C a \mathrm{LB}$ preparations}

Possibly the most beneficial advantage of immobilized enzyme preparations is the capability of biocatalyst recycling thus making the process more economical and environment friendly. Therefore, beside the three best proven 


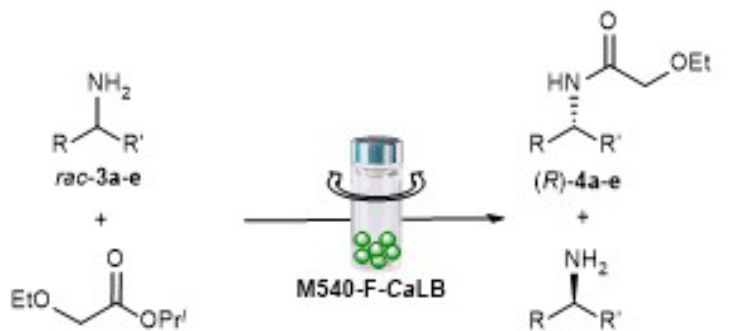

$(S)-3 a-e$

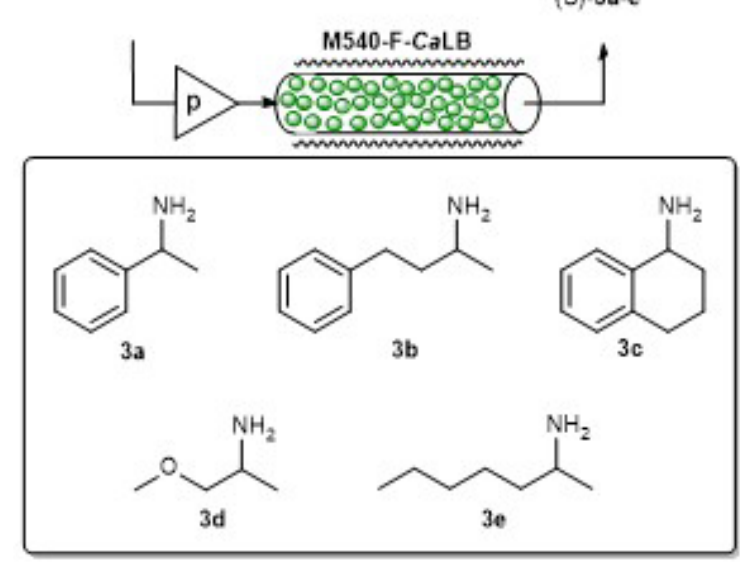

Fig. 4 M540-F- $\mathrm{Ca}$ LB in kinetic resolutions (KRs) of racemic amines rac-3a-e in batch and continuous-flow modes using shaken flasks and packed-bed microreactors

Table 3 Catalytic performance of M540-F-CaLB in kinetic resolution of racemic amines $\mathrm{rac}-\mathbf{3 a}$-e performed in batch ${ }^{\mathrm{b}}$ and in continuousflow $^{\mathrm{c}}$ modes at theoretical conversion $(\sim 50 \%)$

\begin{tabular}{|c|c|c|c|c|}
\hline No. & Substrate & $\begin{array}{c}r \\
{\left[\mu \mathrm{mol} \mathrm{min} \min ^{-1} \mathrm{~g}^{-1}\right]^{\mathrm{e}}}\end{array}$ & $\begin{array}{l}\text { Yield }_{(R)-4 a-e} \\
{[\%]}\end{array}$ & $\begin{array}{l}e e_{(R)-4 \mathrm{a}-\mathrm{e}} \\
{[\%]^{\mathrm{e}, \mathrm{f}}}\end{array}$ \\
\hline 1 & $r a c-\mathbf{3 a}^{\mathrm{b}}$ & 83 & 48 & 99.8 \\
\hline 2 & $r a c-\mathbf{3} \mathbf{a}^{c}$ & 163 & 48 & 99.8 \\
\hline 3 & $r a c-\mathbf{3} \mathbf{b}^{\mathrm{b}}$ & 123 & 47 & 99.2 \\
\hline 4 & $r a c-\mathbf{3} \mathbf{b}^{\mathrm{c}}$ & 163 & 48 & 99.1 \\
\hline 5 & $r a c-3 \mathbf{c}^{\mathrm{b}}$ & 88 & 47 & 98.7 \\
\hline 6 & $r a c-3 \mathbf{c}^{c}$ & 154 & 47 & 98.6 \\
\hline 7 & $r a c-\mathbf{3} \mathbf{d}^{\mathrm{b}}$ & 88 & 42 & 96.5 \\
\hline 8 & $r a c-\mathbf{3} \mathbf{d}^{\mathrm{c}}$ & 154 & 42 & 98.3 \\
\hline 9 & $r a c-3 \mathbf{e}^{\mathrm{b}}$ & 87 & 46 & 96.5 \\
\hline 10 & $r a c-3 \mathbf{e}^{c}$ & 153 & 45 & 99.0 \\
\hline
\end{tabular}

a Reaction conditions: rac-3a-e $(0.646 \mathrm{M})$, isopropyl 2-ethoxyacetate (0.6 equiv.: $0.388 \mathrm{M})$ in dry toluene at $60^{\circ} \mathrm{C}$.

${ }^{\mathrm{b}} \mathrm{KR}$ in batch mode: shaken at $350 \mathrm{rpm}, \mathrm{M} 540-\mathrm{F}-\mathrm{CaLB}$ (50.0 mg).

${ }^{\mathrm{c}} \mathrm{KR}$ in continuous-flow mode: flow rate, $0.10 \mathrm{~mL} \mathrm{~min}^{-1}$; column filling, M540-F-CaLB (209.0 mg).

${ }^{\mathrm{e}}$ Determined by GC.

${ }^{\mathrm{f}}$ Measured from isolated products $(R)$-4a-e.

bisepoxide-activated biocatalysts (M540-C-, M540-D-, M540-F- $C a$ LB), the covalent standard (CV T2-150-CaLB) and the widely applied commercially available adsorptive Novozyme ${ }^{\circledR} 435$ (N435-CaLB) were selected for studying the stability of enzyme preparations during re-cycling over 10 cycles using the KR of rac-1 (reported in the former sections) as reference reaction. Between each cycles, the biocatalysts were filtered off from the reaction mixture, washed with hexane and MTBE to remove organic compounds and dried to determine their exact quantity.

As shown in Fig. 5, every biocatalyst presented decreasing catalytic activity cycle-by-cycle whereas M540-F$\mathrm{Ca} \mathrm{LB}$ has proven the least vulnerable and retained $54 \%$ of its initial effectivity after the $10^{\text {th }}$ cycle while CV T2-150CaLB kept only $23 \%$. This result agreed with our previous experiences, where the carriers with hydrophobic characteristic surface enhanced the immobilization efficiency of $\mathrm{CaLB}$ and herein improved the capability of enzyme preparations to keep their activity for many catalytic cycles.

Besides the biocatalytic performance, mechanical stability of immobilized enzymes is also a crucial parameter which is strongly related to the durability of support material quality. Thus, samples were taken from the biocatalysts during recycling study - the best performing silica microspheres (M540-F-CaLB) and two macroporous acrylic resins (CV T2-150-CaLB and N435-CaLB) - and their morphologies were analyzed by scanning electron microscopy (SEM). As the SEM pictures in Fig. 6 illustrate, appreciable fractions were observed in acrylic polymer based biocatalysts (CV T2-150 and N435) even after the first cycle. The high level of fractionations after the tenth cycle could be related to their low residual activity. In case of the silica-based M540-F-CaLB, fractionation was not a typical event but aggregated particles appeared.

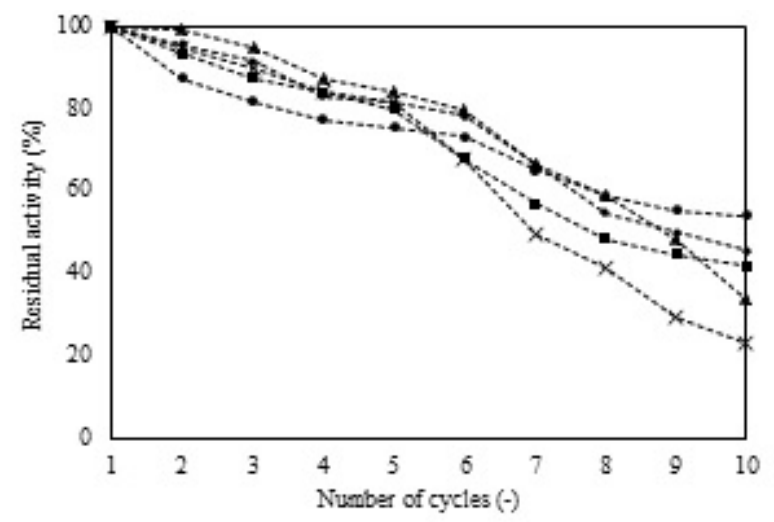

Fig. 5 Recyclability of covalently immobilized M540-C-CaLB ( $)$ M540-D-CaLB (•), M540-F-CaLB (•) and CV T2-150-CaLB (×) preparations was compared to commercially available adsorbed N435-CaLB ( $\mathbf{\Delta})$ in batch mode KR of 1-phenylethanol rac-1 [In each cycles rac-1 (0.393 M) and vinyl acetate (2.6 equiv., 1.022 M) in hexane and MTBE (2:1 volume ratio) were reacted for $30 \mathrm{~min}$ at $30{ }^{\circ} \mathrm{C}$ (Residual activity $(\%)=$ activity of the $\mathrm{n}^{\text {th }}$ cycle / activity of the $1^{\text {st }}$ cycle $\left.\times 100\right)$ ] 


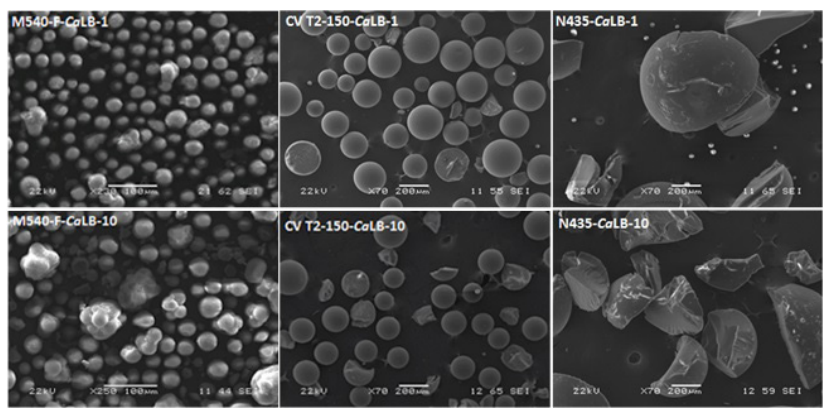

Fig. 6 Scanning electron microscopy images of immobilized $\mathrm{CaLB}$ biocatalysts from reusability tests after $1^{\text {st }}(\mathrm{M} 540-\mathrm{F}-\mathrm{CaLB}-1$, CV T2-150-1, N435-1) and $10^{\text {th }}$ (M540-F-CaLB-10, CV T2-150-10, N435-10) cycles

Aggregation could account for the descending activity due to increasing diffusion resistance owing to the longer pore length and the lower approachable surface area.

In possession of this information, we planned to set our second series of experiments targeting long-term thermal stability. Thus, lifetime of the best performing M540-F-CaLB biocatalyst was investigated by monitoring production of $(R)-1$ phenylethyl acetate $(R)-\mathbf{2}$ in KR of 1-phenylethanol $\mathrm{rac}-1$ in continuous-flow mode for longer operation time $(24 \mathrm{~h})$ at elevated temperatures $\left(60^{\circ} \mathrm{C}, 75\right.$ $\left.{ }^{\circ} \mathrm{C}, 90{ }^{\circ} \mathrm{C}\right)$ using constant flow rate $\left(0.10 \mathrm{~mL} \mathrm{~min}^{-1}\right)$. After the stationary operation has been established, samples were taken after different time $(0.5,1,2,3,4,5,6,10,19$, 20, 21, 22, 23, 24 h).

As the productivity-operation time curves show (Fig. 7, panel A), at all temperatures a linearly decreasing tendency with diverse gradients was noticed. It was not surprising that the biocatalyst started to lose its activity over $60{ }^{\circ} \mathrm{C}$ after elongated reaction time. In accordance with our previous results in KRs of secondary alcohols [73], increasing temperature resulted in lowered of $e e_{(R)-2}$ values (Fig. 7, panel B). Nevertheless, M540-F-CaLB kept more than $96 \%$ of its catalytic activity after 24 hours uninterrupted operation at $60{ }^{\circ} \mathrm{C}$ while $4052 \mathrm{mg}(25 \mathrm{mmol})$ of $(R)-2$ was formed (17-fold of the catalyst mass applied) with excellent enantiomeric purity $\left(e e_{(R)-2}=99.1 \%\right)$.

SEM picture of M540-F-CaLB applied in the packedbed reactor operated in continuous-flow mode revealed no noticeable aggregates or fractions (Fig. 8) - in contrast to the same biocatalyst utilized in batch mode (Fig. 6) - even after a series of experiments (concentration, thermal and continuous operational stability tests). This observation could account for the higher stability of M540-F-CaLB in packed-bed columns as compared to the reactions performed in shaken flasks.
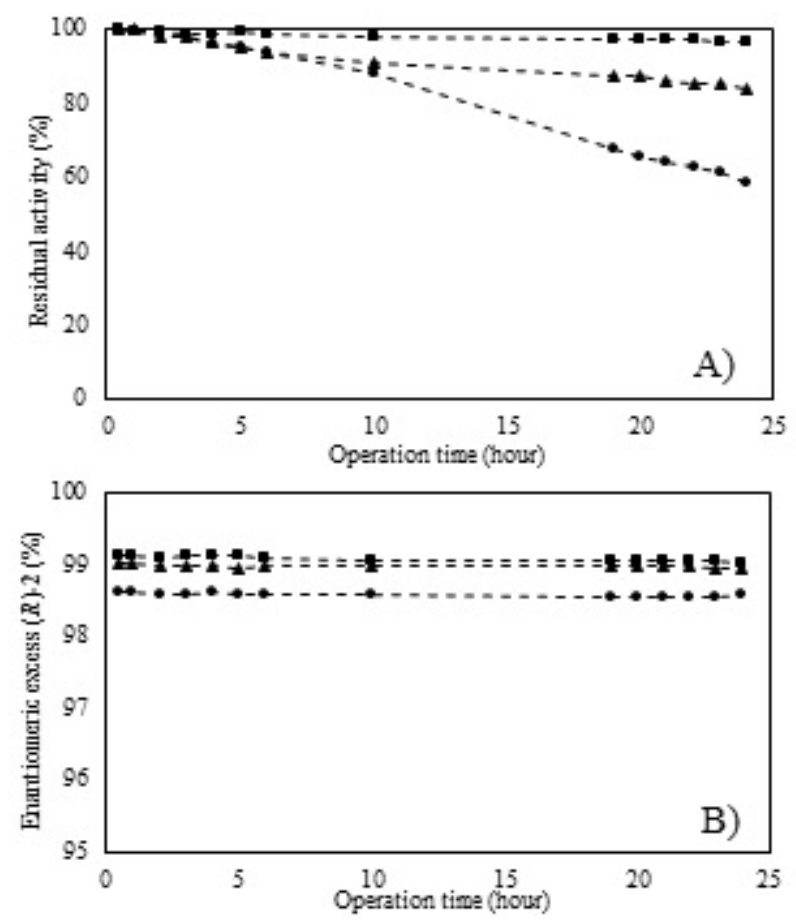

Fig. 7 Uninterrupted operation of packed-bed continuous-flow bioreactors for $24 \mathrm{~h}$ at various temperatures. KRs of 1-phenylethanol rac-1 catalyzed by M540-F-CaLB biocatalyst were performed at a flow rate of $0.10 \mathrm{~mL} \mathrm{~min}^{-1}$ at $60{ }^{\circ} \mathrm{C}(\boldsymbol{\bullet}), 75^{\circ} \mathrm{C}(\boldsymbol{\Delta})$ and $90{ }^{\circ} \mathrm{C}(\bullet)$. Concentration of rac-1 was $48 \mathrm{mg} \mathrm{mL}^{-1}(0.393 \mathrm{M})$ using 2.6 equiv. vinyl acetate as acyl donor (1.022 M) in hexane and $\operatorname{MTBE}(2: 1$ volume ratio).

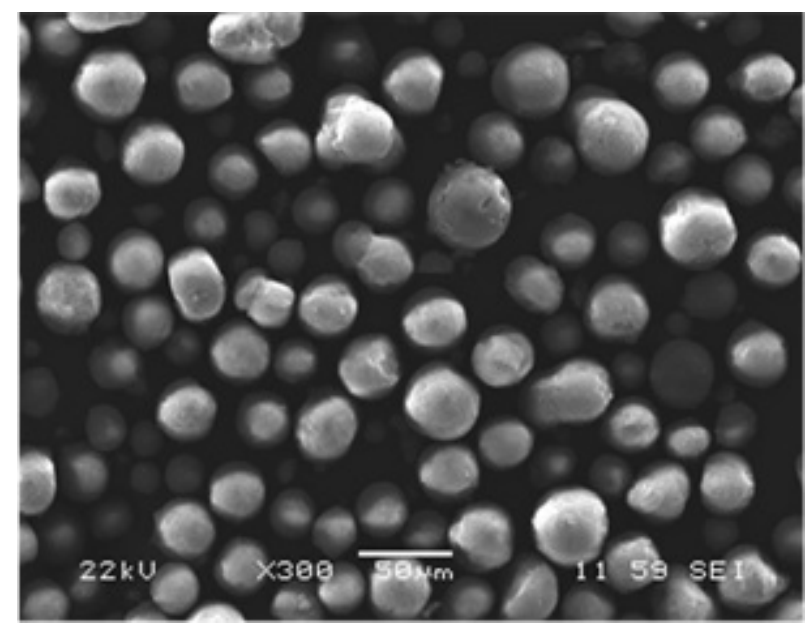

Fig. 8 SEM image of M540-F-CaLB biocatalyst after the concentration, thermal and continuous operational stability tests

\section{Conclusion}

Our study focused on surface activation of MAT540 ${ }^{\mathrm{TM}}$ hollow silica microspheres as support using six bisepoxides with different spacers allowing covalent immobilization of $\mathrm{CaLB}$. To study the biocatalytic performance of the six novel $\mathrm{Ca}$ LB preparations, operation conditions, stability and recyclability of biocatalysts were investigated in 
KRs of 1 phenylethanol $\mathbf{1}$ in batch and continuous-flow microreactors. The biocatalytic parameters and durability of M540-F-CaLB surpassed the corresponding properties of $C a \mathrm{LB}$ on any other bisepoxide-modified presumably due to the poly(ethylene glycol) spacer with moderate hydrophobicity and high flexibility.

The biocatalytic usefulness of M540-F-CaLB was further demonstrated with kinetic resolutions of five different racemic amines rac-3a-e using isopropyl 2 ethoxyacetate as acylating agent under the optimal reaction temperature $\left(60{ }^{\circ} \mathrm{C}\right)$. The formed 2 ethoxyacetamides $(R)$-4a-e could be isolated in good yields ( $\geq 42 \%$ ) and with high enantiomeric excess $\left(e e_{(R)-4 \mathrm{a}-\mathrm{e}} \geq 98.3 \%\right)$. The bisepoxide activated

\section{References}

[1] Kaschani, F., van der Hoorn, R. "Small molecule approaches in plants", Current Opinion in Chemical Biology, 11(1), pp. 88-98, 2007. https://doi.org/10.1016/j.cbpa.2006.11.038

[2] Patel, R. N. "Biocatalytic synthesis of intermediates for the synthesis of chiral drug substances", Current Opinion in Biotechnology, 12(6), pp. 587-604, 2001.

https://doi.org/10.1016/S0958-1669(01)00266-X

[3] Turner, N. J. "Directed evolution drives the next generation of biocatalysts", Nature Chemical Biology, 5(8), pp. 567-573, 2009.

https://doi.org/10.1038/nchembio.203

[4] Akoh, C. C., Chang, S.-W., Lee, G.-C., Shaw, J.-F. "Biocatalysis for the Production of Industrial Products and Functional Foods from Rice and Other Agricultural Produce", Journal of Agricultural and Food Chemistry, 56(22), pp. 10445-10451, 2008.

https://oi.org/10.1021/jf801928e

[5] Sims, R. E. H., Mabee, W., Saddler, J. N., Taylor, M. "An overview of second generation biofuel technologies", Bioresource Technology, 101(6), pp. 1570-1580, 2010.

https://doi.org/10.1016/j.biortech.2009.11.046

[6] Perrone, M. G., Santandrea, E., Giorgio, E., Bleve, L., Scilimati, A., Tortorella, P. "A chemoenzymatic scalable route to optically active (R)-1-(pyridin-3-yl)-2-aminoethanol, valuable moiety of $\beta_{3}$-adrenergic receptor agonists", Bioorganic \& Medicinal Chemistry, 14(4), pp. 1207-1214, 2006.

https://doi.org/10.1016/j.bmc.2005.09.046

[7] Kawasaki, M., Toyooka, N., Saka, T., Goto, M., Matsuya, Y., Kometani, T. "Lipase-mediated preparation of optically active isomers of Rosaphen ${ }^{\circledR}$ ", Journal of Molecular Catalysis B: Enzymatic, 67(1-2), pp. 135-142, 2010.

https://doi.org/10.1016/j.molcatb.2010.07.019

[8] Ren, Z.-Q., Liu, Y., Pei, X.-Q., Wang, H.-B., Wu, Z.-L. "Bioreductive production of enantiopure $(S)$-duloxetine intermediates catalyzed with ketoreductase ChKRED15", Journal of Molecular Catalysis B: Enzymatic, 113, pp. 76-81, 2015. https://doi.org/10.1016/j.molcatb.2015.01.008

[9] Sharma, B., Singh, N., Singh, M., Jaggi, A. S. "Exploitation of HIV protease inhibitor Indinavir as a memory restorative agent in experimental dementia", Pharmacology, Biochemistry, and Behavior, 89(4), pp. 535-545, 2008.

https://doi.org/10.1016/j.pbb.2008.02.012
MAT540 ${ }^{\mathrm{TM}}$ carriers allow general and smooth immobilization of a broad spectrum of enzymes thus creating biocatalysts applicable under continuous-flow conditions with high operational stability.

\section{Acknowledgements}

The authors thank to Dr. Diána Weiser for SEM measurements and $O M$ is grateful for the financial support of the Pro Progressio Foundation (Budapest Hungary). This work was supported by the Higher Education Excellence Program of the Ministry of Human Capacities in the frame of Biotechnology research area of Budapest University of Technology and Economics (BME FIKP-BIO).

[10] Müller, M. "Chemoenzymatic Synthesis of Building Blocks for Statin Side Chains", Angewandte Chemie International Edition, 44(3), pp. 362-365, 2005. https://doi.org/10.1002/anie.200460852

[11] Pan, X., Li, X., Lu, Q., Yu, W., Li, W., Zhang, Q., Deng, F., Liu, F. "Efficient synthesis of sitagliptin phosphate, a novel DPP-IV inhibitor, via a chiral aziridine intermediate", Tetrahedron Letters, 54(50), pp. 6807-6809, 2013. https://doi.org/10.1016/j.tetlet.2013.09.136

[12] Bastos, M. M., Costa, C. C. P., Bezerra, T. C., da Silva, F. de C., Boechat, N. "Efavirenz a nonnucleoside reverse transcriptase inhibitor of first-generation: Approaches based on its medicinal chemistry", European Journal of Medicinal Chemistry, 108, pp. $455-465,2016$. https://doi.org/10.1016/j.ejmech.2015.11.025

[13] Guan, Z., Li, L.-Y., He, Y.-H. "Hydrolase-catalyzed asymmetric carbon-carbon bond formation in organic synthesis", RSC Advances, 5(22), pp. 16801-16814, 2015. https://oi.org/10.1039/C4RA11462K

[14] Lin, H., Liu, J.-Y., Wang, H.-B., Ahmed, A. A. Q., Wu, Z.-L. "Biocatalysis as an alternative for the production of chiral epoxides: A comparative review", Journal of Molecular Catalysis B: Enzymatic, 72(3-4), pp. 77-89, 2011. https://doi.org/10.1016/j.molcatb.2011.07.012

[15] Chauhan, M. S., Singh, S. "Asymmetric reduction of ketones catalyzed by $\alpha, \alpha$-diphenyl-(L)-prolinol modified with imidazolium ionic liquid and $\mathrm{BH}_{3} \cdot \mathrm{SMe}_{2}$ as a recoverable catalyst", Journal of Molecular Catalysis A: Chemical, 398, pp. 184-189, 2015. https://doi.org/10.1016/j.molcata.2014.12.009

[16] Musolino, S. F., Ojo, O. S., Westwood, N. J., Taylor, J. E. "Isothiourea-Catalysed Acylative Kinetic Resolution of ArylAlkenyl ( $\mathrm{sp}^{2}$ vs. $\mathrm{sp}^{2}$ ) Substituted Secondary Alcohols", Chemistry A European Journal, 22(52), pp. 18916-18922, 2016. https://doi.org/10.1002/chem.201604788

[17] Zell, D., Schreiner, P. R. "Aclytion-Type Reactions: Synthesis of Esters via Acyl Transfer", In: Knochel, P., Molander, G. A. (eds.) Comprehensive Organic Synthesis, 2nd ed., Elsevier, Amsterdam, Netherlands, 2014, pp. 296-353. 
[18] Capper, P., Zharikov, E. "24 - Oscillatory-Driven Fluid Flow Control during Crystal Growth from the Melt", In: Rudolph, P. (ed.) Handbook of Crystal Growth, 2nd ed., Elsevier, Amsterdam, Netherlands, 2015, pp. 951-993.

https://doi.org/10.1016/B978-0-444-63303-3.00024-9

[19] Pálovics, E., Szeleczky, Z., Bagi, P., Faigl, F., Fogassy, E. "Regularities between Separations of Enantiomeric and Diastereoisomeric Mixtures. Prediction of the Efficiency of Diastereomeric / Enantiomeric Separations on the Basis of Behaviour of Enantiomeric Mixtures", Periodica Polytechnica Chemical Engineering, 59(1), pp. 26-37, 2015.

https://doi.org/10.3311/PPch.7328

[20] Kida, T., Iwamoto, T., Asahara, H., Hinoue, T., Akashi, M. "Chiral Recognition and Kinetic Resolution of Aromatic Amines via Supramolecular Chiral Nanocapsules in Nonpolar Solvents", Journal of the American Chemical Society, 135(9), pp. 3371-3374, 2013. https://doi.org/10.1021/ja312367k

[21] Zhang, R., Xu, Y., Xiao, R. "Redesigning alcohol dehydrogenases / reductases for more efficient biosynthesis of enantiopure isomers", Biotechnology Advances, 33(8), pp. 1671-1684, 2015. https://doi.org/10.1016/j.biotechadv.2015.08.002

[22] Ni, Y., Xu, J.-H. "Biocatalytic ketone reduction: A green and efficient access to enantiopure alcohols", Biotechnology Advances, 30(6), pp. 1279-1288, 2012. https://doi.org/10.1016/j.biotechadv.2011.10.007

[23] Mallin, H., Höhne, M., Bornscheuer, U. T. "Immobilization of $(R)$ - and $(S)$-amine transaminases on chitosan support and their application for amine synthesis using isopropylamine as donor", Journal of Biotechnology, 191, pp. 32-37, 2014 https://doi.org/10.1016/j.jbiotec.2014.05.015

[24] Schober, M., Faber, K. "Inverting hydrolases and their use in enantioconvergent biotransformations", Trends in Biotechnology, 31(8), pp. $468-478,2013$ https://doi.org/10.1016/j.tibtech.2013.05.005

[25] van Rantwijk, F., Stolz, A. "Enzymatic cascade synthesis of $(S)$-2-hydroxycarboxylic amides and acids: Cascade reactions employing a hydroxynitrile lyase, nitrile-converting enzymes and an amidase", Journal of Molecular Catalysis B: Enzymatic, 114, pp. $25-30,2015$. https://doi.org/10.1016/j.molcatb.2014.08.012

[26] Kapoor, M., Gupta, M. N. "Lipase promiscuity and its biochemical applications", Process Biochemistry, 47(4), pp. 555-569, 2012. https://doi.org/10.1016/j.procbio.2012.01.011

[27] Machado, A. C. O., da Silva, A. A. T., Borges, C. P., Simas, A. B. C., Freire, D. M. G. "Kinetic resolution of $(R, S)$-1,2-isopropylidene glycerol (solketal) ester derivatives by lipases", Journal of Molecular Catalysis B: Enzymatic, 69(1-2), pp. 42-46, 2011. https://doi.org/10.1016/j.molcatb.2010.12.008

[28] Guo, J., Chen, C.-P., Wang, S.-G., Huang, X.-J. "A convenient test for lipase activity in aqueous-based solutions", Enzyme and Microbial Technology, 71, pp. 8-12, 2015. https://doi.org/10.1016/j.enzmictec.2015.01.005

[29] Höhne, M., Bornscheuer, U. T. "Biocatalytic Routes to Optically Active Amines", ChemCatChem, 1(1), pp. 42-51, 2009. https://doi.org/10.1002/cctc.200900110
[30] Bornscheuer, U. T. "Immobilizing Enzymes: How to Create More Suitable Biocatalysts", Angewandte Chemie International Edition, 42(29), pp. 3336-3337, 2003.

https://doi.org/10.1002/anie.200301664

[31] Barbosa, O., Ortiz, C., Berenguer-Murcia, Á., Torres, R., Rodrigues, R. C., Fernandez-Lafuente, R. "Strategies for the onestep immobilization-purification of enzymes as industrial biocatalysts", Biotechnology Advances, 33(5), pp. 435-456, 2015. https://doi.org/10.1016/j.biotechadv.2015.03.006

[32] Mateo, C., Palomo, J. M., Fernandez-Lorente, G., Guisan, J. M., Fernandez-Lafuente, R. "Improvement of enzyme activity, stability and selectivity via immobilization techniques", Enzyme and Microbial Technology, 40(6), pp. 1451-1463, 2007. https://doi.org/10.1016/j.enzmictec.2007.01.018

[33] Gutarra, M. L.E., Miranda, L. S. M., de Souza, R. O. M. A. "Chapter 4 - Enzyme Immobilization for Organic Synthesis", In: Goswami, A., Stewart, J. (eds.) Organic Synthesis Using Biocatalysis, 1st ed., Elsevier, Amsterdam, Netherlands, 2016, pp. 99-126. https://doi.org/10.1016/B978-0-12-411518-7.00004-4

[34] Rodrigues, R. C., Ortiz, C., Berenguer-Murcia, Á., Torres, R., Fernández-Lafuente, R. Chemical Society Reviews, 42(15), pp. 6290-6307, 2013. https://doi.org/10.1039/C2CS35231A

[35] Tran, D. N., Balkus Jr., K. J. "Perspective of Recent Progress in Immobilization of Enzymes", ACS Catalysis, 1(8),pp. 956-968, 2011. https://doi.org/10.1021/cs200124a

[36] Balcão, V. M., Vila, M. M. D. C. "Structural and functional stabilization of protein entities: state-of-the-art", Advanced Drug Delivery Reviews, 93, pp. 25-41, 2015. https://doi.org/10.1016/j.addr.2014.10.005

[37] Dahili, L. A., Feczkó, T. "Cross-linking of Horseradish Peroxidase Enzyme to Fine Particles Generated by Nano Spray Dryer B-90", Periodica Polytechnica Chemical Engineering, 59(3), pp. 209-214, 2015. https://doi.org/10.3311/PPch.7590

[38] Nagy-Győr, L., Boros, Z., Poppe, L. "Immobilization of lipases from Rhizomucor miehei and Thermomyces lanuginosus by adsorption on variously grafted silica gels", Periodica Polytechnica Chemical Engineering, 57(1-2), pp. 37-40, 2013. https://doi.org/10.3311/PPch.2168

[39] Hernandez, K., Fernandez-Lafuente, R. "Control of protein immobilization: Coupling immobilization and site-directed mutagenesis to improve biocatalyst or biosensor performance", Enzyme and Microbial Technology, 48(2), pp. 107-122, 2011. https://doi.org/10.1016/j.enzmictec.2010.10.003

[40] Garcia-Galan, C., Berenguer-Murcia, Á., Fernandez-Lafuente, R., Rodrigues, R. C. "Potential of Different Enzyme Immobilization Strategies to Improve Enzyme Performance", Advanced Synthesis \& Catalysis, 353(16), pp. 2885-2904, 2011.

https://doi.org/10.1002/adsc.201100534

[41] Franssen, M. C. R., Steunenberg, P., Scott, E. L., Zuilhof, H., Sanders, J. P. M. "Immobilised enzymes in biorenewables production", Chemical Society Reviews, 42(15), pp. 6491-6533, 2013. https://doi.org/10.1039/C3CS00004D 
[42] Poppe, J. K., Costa, A. P. O., Brasil, M. C., Rodrigues, R. C., Ayub, M. A. Z. "Multipoint covalent immobilization of lipases on aldehyde-activated support: Characterization and application in transesterification reaction", Journal of Molecular Catalysis B: Enzymatic, 94, pp. 57-62, 2013. https://doi.org/10.1016/j.molcatb.2013.05.017

[43] Boros, Z., Hornyánszky, G. Nagy, J., Poppe, L. "From Synthetic Chemistry and Stereoselective Biotransformations to Enzyme Biochemistry - The Bioorganic Chemistry Group at the Budapest University of Technology and Economics", Periodica Polytechnica Chemical Engineering, 59(1), pp. 59-71, 2015. https://doi.org/10.3311/PPch.7390

[44] Sanfilippo, C., Nicolosi, G., Patti, A. "Milnacipran as a challenging example of aminomethyl substrate for lipase-catalyzed kinetic resolution", Journal of Molecular Catalysis B: Enzymatic, 104, pp. 82-86, 2014.

https://doi.org/10.1016/j.molcatb.2014.03.015

[45] Silva, M. V. M., Bassut, J. F., Junior, I. I., de Souza, S. P., Estrada, M. L. G., Miranda, L. S. M., de Souza, R. O. M. A. "Lipase immobilization towards improved productivity on kinetic resolutions by a continuous-flow process", RSC Advances, 5(124), pp. 102409-102415, 2015.

https://doi.org/10.1039/C5RA17961K

[46] Boros, Z., Falus, P., Márkus, M., Weiser, D., Oláh, M., Hornyánszky, G., Nagy, J., Poppe, L. "How the mode of Candida antarctica lipase B immobilization affects the continuous-flow kinetic resolution of racemic amines at various temperatures", Journal of Molecular Catalysis B: Enzymatic, 85-86, pp. 119-125, 2013. https://doi.org/10.1016/j.molcatb.2012.09.004

[47] Oláh, M., Boros, Z., Hornyánszky, G., Poppe, L. "Isopropyl 2-ethoxyacetate - an efficient acylating agent for lipase-catalyzed kinetic resolution of amines in batch and continuous-flow modes", Tetrahedron, 72(46), pp. 7249-7255, 2016. https://doi.org/10.1016/j.tet.2015.12.046

[48] Illanes, A. "1.04 - Immobilized Biocatalysts", In: Moo-Young, M. (ed.) Comprehensive Biotechnology, 2nd ed., Elsevier, Amsterdam, Netherlands, Volume 1, 2011, pp. 25-39.

https://doi.org/10.1016/B978-0-08-088504-9.00006-4

[49] Cowan, D. A., Fernandez-Lafuente, R. "Enhancing the functional properties of thermophilic enzymes by chemical modification and immobilization", Enzyme and Microbial Technology, 49(4), pp. 326-346, 2011.

https://doi.org/10.1016/j.enzmictec.2011.06.023

[50] Idris, A., Bukhari, A. "Immobilized Candida antarctica lipase B: Hydration, stripping off and application in ring opening polyester synthesis", Biotechnology Advances, 30(3), pp. 550-563, 2012. https://doi.org/10.1016/j.biotechadv.2011.10.002

[51] Mateo, C., Palomo, J. M., Fuentes, M., Betancor, L., Grazu, V., López-Gallego, F., Pessela, B. C. C., Hidalgo, A., FernándezLorente, G., Fernández-Lafuente, R., Guisán, J. M. "Glyoxyl agarose: A fully inert and hydrophilic support for immobilization and high stabilization of proteins", Enzyme and Microbial Technology, 39(2), pp. 274-280, 2006.

https://doi.org/10.1016/j.enzmictec.2005.10.014
[52] Mendes, A. A., de Castro, H. F., Andrade, G. S. S., Tardioli, P. W., Giordano, R. de L. C. "Preparation and application of epoxychitosan / alginate support in the immobilization of microbial lipases by covalent attachment", Reactive and Functional Polymers, 73(1), pp. 160-167, 2013.

https://doi.org/10.1016/j.reactfunctpolym.2012.08.023

[53] Mateo, C., Fernández-Lorente, G., Abian, O., Fernández-Lafuente, R., Guisán, J. M. "Multifunctional Epoxy Supports: A New Tool To Improve the Covalent Immobilization of Proteins. The Promotion of Physical Adsorptions of Proteins on the Supports before Their Covalent Linkage", Biomacromolecules, 1(4), pp. 739-745, 2000. https://doi.org/10.1021/bm000071q

[54] Mateo, C., Grazú, V., Pessela, B. C. C., Montes, T., Palomo, J. M., Torres, R., López-Gallego, F., Fernández-Lafuente, R., Guisán, J. M. "Advances in the design of new epoxy supports for enzyme immobilization-stabilization", Biochemical Society Transactions, 35(6), pp. 1593-1601, 2007. https://doi.org/10.1042/BST0351593

[55] Yuce-Dursun, B., Cigil, A. B., Dongez, D., Kahraman, M. V., Ogan, A., Demir, S. "Preparation and characterization of sol-gel hybrid coating films for covalent immobilization of lipase enzyme", Journal of Molecular Catalysis B: Enzymatic, 127, pp. 18-25, 2016. https://doi.org/10.1016/j.molcatb.2016.02.007

[56] Ashjari, M., Mohammadi, M., Badri, R. "Chemical amination of Rhizopus oryzae lipase for multipoint covalent immobilization on epoxy-functionalized supports: Modulation of stability and selectivity", Journal of Molecular Catalysis B: Enzymatic, 115, pp. 128-134, 2015. https://doi.org/10.1016/j.molcatb.2015.02.011

[57] Bencze, L. Cs., Bartha-Vári, J. H., Katona, G., Toşa, M. I., Paizs, Cs., Irimie, F.-D. "Nanobioconjugates of Candida antarctica lipase B and single-walled carbon nanotubes in biodiesel production", Bioresource Technology, 200, pp. 853-860, 2016. https://doi.org/10.1016/j.biortech.2015.10.072

[58] Gandomkar, S., Habibi, Z., Mohammadi, M., Yousefi, M., Salimi, S. "Enantioselective resolution of racemic ibuprofen esters using different lipases immobilized on epoxy-functionalized silica", Biocataysis and Agricultural Biotechnology, 4(4), pp. 550-554, 2015. https://doi.org/10.1016/j.bcab.2015.10.007

[59] Zhang, D.-H., Peng, L.-J., Wang, Y., Li, Y.-Q. "Lipase immobilization on epoxy-activated poly(vinyl acetate-acrylamide) microspheres", Colloids and Surfaces B: Biointerfaces, 129, pp. 206210, 2015.

https://doi.org/10.1016/j.colsurfb.2015.03.056

[60] Cui, C., Tao, Y., Ge, C., Zhen, Y., Chen, B., Tan, T. "Synergistic effects of amine and protein modified epoxy-support on immobilized lipase activity", Colloids and Surfaces B: Biointerfaces, 133, pp. 51-57, 2015. https://doi.org/10.1016/j.colsurfb.2015.05.045

[61] Kamra, T., Chaudhary, S., Xu, C., Johansson, N., Montelius, L., Schnadt, J., Ye, L. "Covalent immobilization of molecularly imprinted polymer nanoparticles using an epoxy silane", Journal of Colloid and Interface Science, 445, pp. 277-284, 2015. https://doi.org/10.1016/j.jcis.2014.12.086 
[62] Sun, B., Zhou, G., Zhang, H. "Synthesis, functionalization, and applications of morphology-controllable silica-based nanostructures: A review", Progress in Solid State Chemistry, 44(1), pp. 1-19, 2016. https://doi.org/10.1016/j.progsolidstchem.2016.01.001

[63] Abaházi, E., Boros, Z., Poppe, L. "Additives Enhancing the Catalytic Properties of Lipase from Burkholderia cepacia Immobilized on Mixed-Function-Grafted Mesoporous Silica Gel", Molecules, 19(7), pp. 9818-9837, 2014. https://doi.org/10.3390/molecules19079818

[64] Garmroodi, M., Mohammadi, M., Ramazani, A., Ashjari, M., Mohammadi, J., Sabour, B., Yousefi, M. "Covalent binding of hyper-activated Rhizomucor miehei lipase (RML) on hetero-functionalized siliceous supports", International Journal of Biological Macromolecules, 86, pp. 208-215, 2016. https://doi.org/10.1016/j.ijbiomac.2016.01.076

[65] Sujandi, Prasetyanto, E. A., Park, S.-E. "Synthesis of short-channeled amino-functionalized SBA-15 and its beneficial applications in base-catalyzed reactions", Applied Catalysis A: General, 350(2), pp. 244-251, 2008 https://doi.org/10.1016/j.apcata.2008.08.020

[66] Chong, A. S. M., Zhao, X. S., Kustedjo, A. T., Qiao, S. Z. "Functionalization of large-pore mesoporous silicas with organosilanes by direct synthesis", Microporous and Mesoporous Materials, 72(1-3), pp. 33-42, 2004. https://doi.org/10.1016/j.micromeso.2004.04.015

[67] Brena, B. M., Batista-Viera, F. "Immobilization of Enzymes", In: Guisan, J. M. (ed.) Immobilization of Enzymes and Cells, Humana Press, Berlin, Germany, 2006, pp. 15-33. https://doi.org/10.1007/978-1-59745-053-9

[68] Bolivar, J. M., Eisl, I., Nidetzky, B. "Advanced characterization of immobilized enzymes as heterogeneous biocatalysts", Catalysis Today, 259(1), pp. 66-80, 201(5)6. https://doi.org/10.1016/j.cattod.2015.05.004

[69] Arica, M. Y., Hasirci, V., Alaeddinoğlu, N. G. "Covalent immobilization of $\alpha$-amylase onto pHEMA microspheres: preparation and application to fixed bed reactor", Biomaterials, 16(10), pp. 761-768, 1995. https://doi.org/10.1016/0142-9612(95)99638-3

[70] Carvalho, F., Fernandes, P. "Packed bed enzyme microreactor: Application in sucrose hydrolysis as proof-of-concept", Biochemical Engineering Journal, 104, pp. 74-81, 2015. https://doi.org/10.1016/j.bej.2015.04.023

[71] Abaházi, E., Lestál, D., Boros, Z., Poppe, L. "Tailoring the Spacer Arm for Covalent Immobilization of Candida antarctica Lipase B - Thermal Stabilization by Bisepoxide-Activated Aminoalkyl Resins in Continuous-Flow Reactors", Molecules, 21(6), pp. 767784, 2016. https://doi.org/10.3390/molecules21060767

[72] Chen, C. S., Fujimoto, Y., Girdaukas, G., Sih, C. J. "Quantitative analyses of biochemical kinetic resolutions of enantiomers", Journal of American Chemical Society, 104(25), pp. 7294-7299, 1982. https://doi.org/10.1021/ja00389a064

[73] Csajági, Cs., Szatzker, G., Tőke, E. R., Ürge, L., Darvas, F., Poppe, L. "Enantiomer selective acylation of racemic alcohols by lipases in continuous-flow bioreactors", Tetrahedron: Asymmetry, 19(2), pp. 237-246, 2008.

https://doi.org/10.1016/j.tetasy.2008.01.002
[74] Weiser, D., Nagy, F., Bánóczi, G., Oláh, M., Farkas, A. Szilágyi, A., László, K., Gellért, Á., Marosi, Gy. Kemény, S., Poppe, L. "Immobilization engineering - How to design advanced sol-gel systems for biocatalysis?", Green Chemistry, 19(16), pp. 3927-3937, 2017 https://doi.org/10.1039/C7GC00896A

[75] Hellner, G., Boros, Z., Tomin, A., Poppe, L. "Novel Sol-Gel Lipases by Designed Bioimprinting for Continuous-Flow Kinetic Resolutions", Advanced Synthesis \& Catalysis, 353(13), pp. 24812491, 2011.

https://doi.org/10.1002/adsc.201100329

[76] Li, Z., Liu, H., Zhao, G., Wang, P., Wang, L., Wu, H., Fang, X., Sun, X., Wu, X., Zheng, Z. "Enhancing the performance of a phospholipase $\mathrm{A}_{1}$ for oil degumming by bio-imprinting and immobilization", Journal of Molecular Catalysis B: Enzymatic, 123, pp. 122-131, 2016.

https://doi.org/10.1016/j.molcatb.2015.11.018

[77] Liu, Y., Guo, C., Sun, X.-T., Liu, C.-Z. "Improved performance of Yarrowia lipolytica lipase-catalyzed kinetic resolution of $(\mathrm{R}$, S)-2-octanol by an integrated strategy of interfacial activation, bioimprinting and immobilization", Bioresource Technology, 142, pp. 415-419, 2013. https://doi.org/10.1016/j.biortech.2013.05.045

[78] Barbosa, O., Ortiz, C., Torres, R., Fernandez-Lafuente, R. "Effect of the immobilization protocol on the properties of lipase B from Candida antarctica in organic media: Enantiospecific production of atenolol acetate", Journal of Molecular Catalysis B: Enzymatic, 71(3-4), pp. 124-132, 2011

https://doi.org/10.1016/j.molcatb.2011.04.008

[79] Wachtmeister, J., Rother, D. "Recent advances in whole cell biocatalysis techniques bridging from investigative to industrial scale" Current Opinion in Biotechnology, 42, pp. 169-177, 2016. https://doi.org/10.1016/j.copbio.2016.05.005

[80] Shakeri, M., Engström, K., Sandström, A. G., Bäckvall, J.-E. "Highly Enantioselective Resolution of $\beta$-Amino Esters by Candida antarctica Lipase A Immobilized in Mesocellular Foam: Application to Dynamic Kinetic Resolution", ChemCatChem, 2(5), pp. 534-538, 2010. https://doi.org/10.1002/cctc.201000027

[81] Päiviö, M., Perkiö, P., Kanerva, L. T. "Solvent-free kinetic resolution of primary amines catalyzed by Candida antarctica lipase B: effect of immobilization and recycling stability", Tetrahedron: Asymmetry, 23(3-4), pp. 230-236, 2012. https://doi.org/10.1016/j.tetasy.2012.02.008

[82] Born, S., O'Neal, E., Jensen, K. F. "9.03 Organic Synthesis in Small Scale Continuous Flow: Flow Chemistry", In: Knochel, P., Molander, G. A. (eds.) Comprehensive Organic Synthesis II, 2nd ed., Elsevier, Amsterdam, Netherlands, Volume 9, 2014, pp. 54-93. https://doi.org/10.1016/B978-0-08-097742-3.00912-5 